\title{
Complement system part II: role in immunity
}

\author{
Nicolas S. Merle ${ }^{1,2,3}$, Remi Noe $e^{1,2,3,4}$, Lise Halbwachs-Mecarelli, 1,2,3, \\ Veronique Fremeaux-Bacchi ${ }^{1,2,3,5}$ and Lubka T. Roumenina ${ }^{1,2,3 *}$
}

${ }^{1}$ UMRS 1138, Centre de Recherche des Cordeliers, INSERM, Paris, France, ${ }^{2}$ UMRS 1138, Centre de Recherche des Cordeliers, Sorbonne Paris Cité, Université Paris Descartes, Paris, France, ${ }^{3}$ UMRS 1138, Centre de Recherche des Cordeliers, Sorbonne Universités, UPMC Université Paris 06, Paris, France, ${ }^{4}$ Ecole Pratique des Hautes Études (EPHE), Paris, France, ${ }^{5}$ Service d'Immunologie Biologique, Assistance Publique-Hôpitaux de Paris, Hôpital Européen Georges-Pompidou, Paris, France

The complement system has been considered for a long time as a simple lytic cascade, aimed to kill bacteria infecting the host organism. Nowadays, this vision has changed and it is well accepted that complement is a complex innate immune surveillance system, playing a key role in host homeostasis, inflammation, and in the defense against pathogens. This review discusses recent advances in the understanding of the role of complement in physiology and pathology. It starts with a description of complement contribution to the normal physiology (homeostasis) of a healthy organism, including the silent clearance of apoptotic cells and maintenance of cell survival. In pathology, complement can be a friend or a foe. It acts as a friend in the defense against pathogens, by inducing opsonization and a direct killing by C5b-9 membrane attack complex and by triggering inflammatory responses with the anaphylatoxins $\mathrm{C} 3 \mathrm{a}$ and $\mathrm{C} 5 \mathrm{a}$. Opsonization plays also a major role in the mounting of an adaptive immune response, involving antigen presenting cells, T-, and B-lymphocytes. Nevertheless, it can be also an enemy, when pathogens hijack complement regulators to protect themselves from the immune system. Inadequate complement activation becomes a disease cause, as in atypical hemolytic uremic syndrome, C3 glomerulopathies, and systemic lupus erythematosus. Age-related macular degeneration and cancer will be described as examples showing that complement contributes to a large variety of conditions, far exceeding the classical examples of diseases associated with complement deficiencies. Finally, we discuss complement as a therapeutic target.

Keywords: complement system, adaptive immunity, crosstalk TLR-complement, pathogen strategies for immune evasion, complement in cancer, complement and innate immunity, complement-related diseases, anaphylatoxins

\section{The Complement System}

Complement system represents a major part of the innate immunity. It is a cascade of soluble proteins and membrane expressed receptors and regulators (Figure 1), which operates in plasma, in tissues, on cell surface, and even within the cell. It is composed of more than 40 proteins, the soluble ones being produced mainly by the liver. Complement was discovered at the end of the nineteenth century and described as a "factor" or "principle" capable to induce bacterial lysis. 


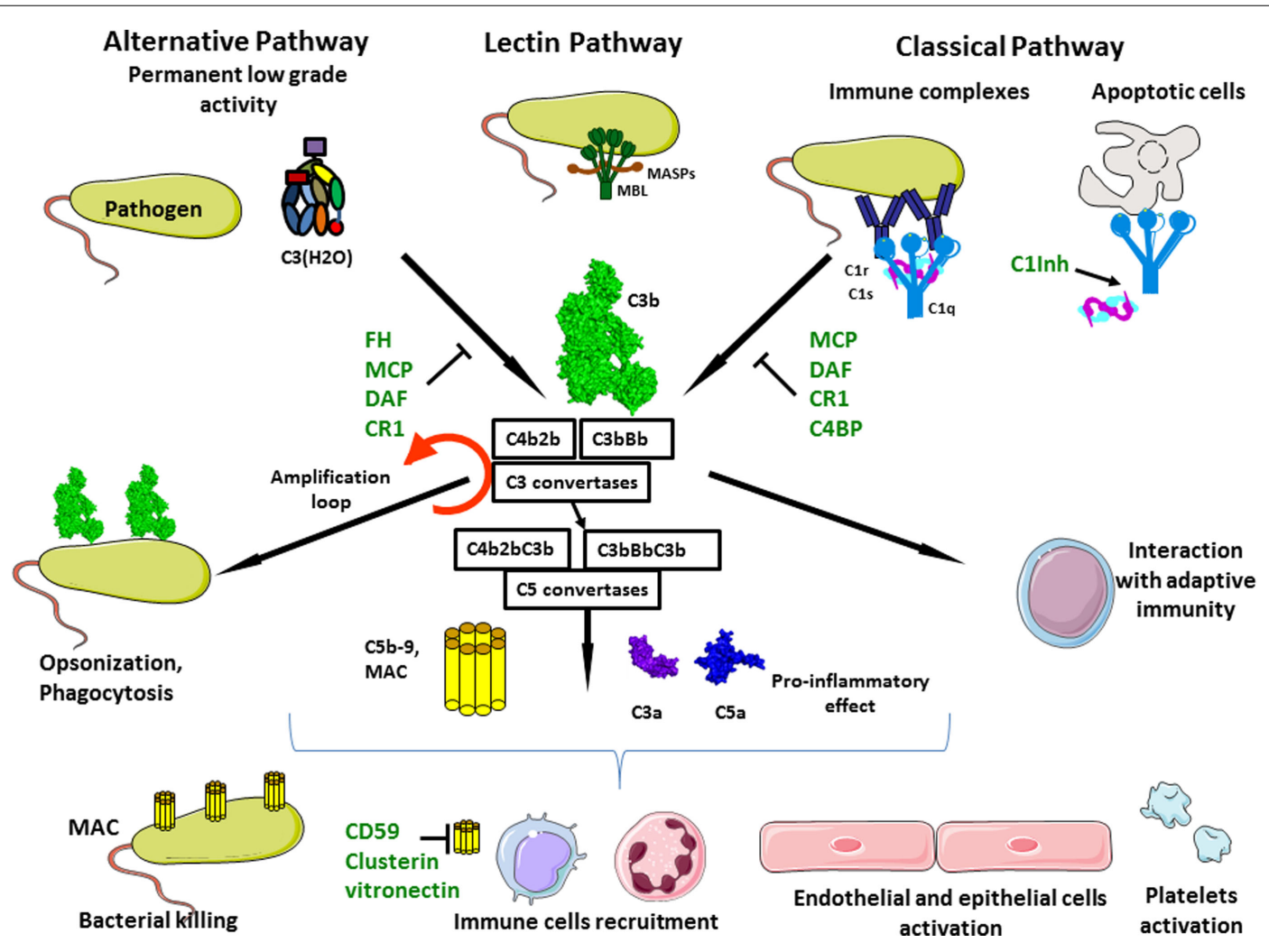

FIGURE 1 | Complement activation. Complement system is composed of three different pathways. $\mathrm{CP}$ is activated by immune complex formation on pathogen surface and by calreticulin expressed on apoptotic cells, leading to C1 complex association. LP recognizes mannose-terminating glycan on pathogens leading to MBL MASP complex activation. Both induce formation of the classical C3 convertase C4b2a. AP is permanently activated at low level by spontaneous hydrolysis of $\mathrm{C} 3$ into $\mathrm{C} 3\left(\mathrm{H}_{2} \mathrm{O}\right)$. Lack of complement inhibitor on pathogens induces alternative $\mathrm{C} 3$ convertase activation $\mathrm{C} 3 \mathrm{bBb}$. Complement activation leads to opsonization and phagocytosis by C3b deposition, bacterial lysis by C5b-9 complex formation and inflammation by recruitment of immune cells, endothelial and epithelial cells activation, and platelets activation.
After that, for a long time, complement system has been considered as a supportive part of the innate immunity and received relatively little attention from the immunologists. Over the years, it became clear that complement has versatile functions and that its action extends far beyond the simple bactericidal activity. In a healthy individual, it orchestrates the immunologically silent clearance of host cells after their programed cell death. Complement cascade is activated immediately after encountering the pathogen. Hence, complement participates in pathogen opsonization, tagging it for engulfment by antigen presenting cells (APC); it plays a central role in the inflammatory process and modulates the activity of T- and B-cells. After generation of pathogenspecific antibodies, complement contributes in the clearance of immune complexes and pathogen elimination. Studies over the years demonstrated that complement takes part in nearly every step of the immune reaction and that it deserves a central position in the immunological research. Unfortunately, the lack of coherence in complement proteins nomenclature and the complexity of the enzymatic cascade render complement one of the "most complicated and incomprehensible" parts of immunology and is frequently avoided by students and scientists. With this review, we aim to underline the crucial importance of complement in physiology and pathology.

\section{Complement in Physiology}

\section{Sampling for Foreign and Altered Cells}

The main complement rule is that everything that is not specifically protected has to be attacked. Host cells carry an armamentarium of "don't attack me" molecules, which are either expressed by the cell or recruited to the cell membrane from the plasma. Therefore, any cell, debris, microorganism, or artificial material lacking these molecules (and carrying $-\mathrm{OH}$ or $-\mathrm{NH}_{2}$ chemical groups, which is the case of all biological and most synthetic materials) will represent an "activating surface" and will support complement deposition, i.e., covalent binding of C3b, an activated form of the central complement component $\mathrm{C} 3$. This action is provided by the so-called alternative complement pathway, which is permanently active and constantly probes the environment for the presence of activating surfaces (Figure 2A). In addition, several pattern recognition molecules recognize material that has to be eliminated, such as apoptotic cells, debris, pathogens, immune complexes, and activate the classical and lectin complement pathways (CP and LP) (Figure 2B). All pathways converge at the point of $\mathrm{C} 3$ cleavage, which results in generation of bioactive fragments $\mathrm{C} 3 \mathrm{a}$ and $\mathrm{C} 3 \mathrm{~b}$. C3b binds covalently to any surface and, if it is not specifically protected. The level of C3 deposition is increased by the so-called 

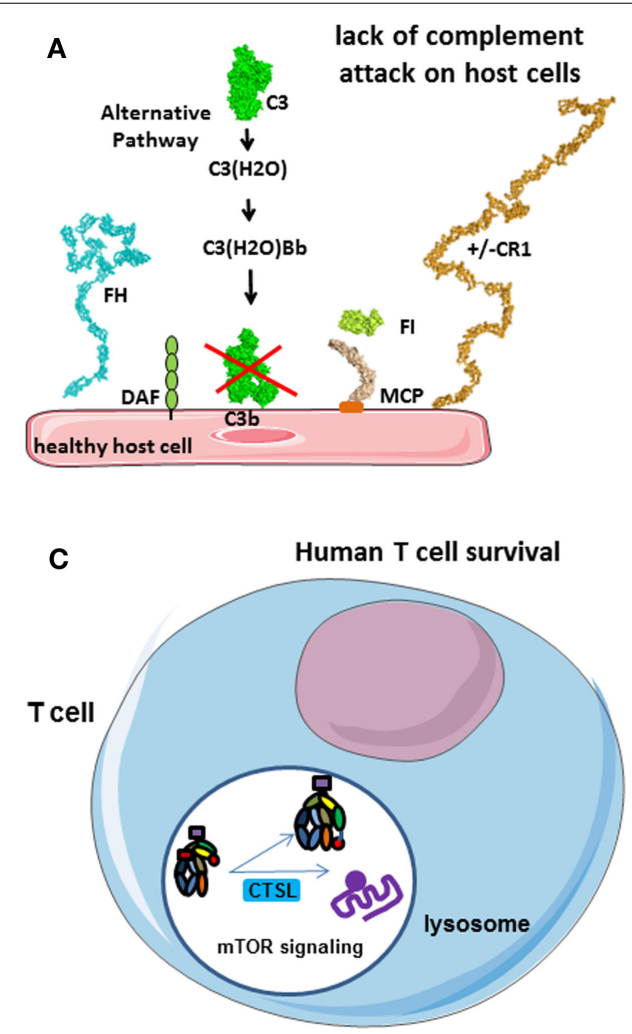

FIGURE 2 | Role of complement in physiology. (A) Protection of host cells against complement. Complement AP is permanently activated and deposits C3b molecules to any surface. On host cells, these C3b molecules are rapidly inactivated by different membrane expressed or plasma complement regulators. (B) Immunologically silent clearance of apoptotic cells. Limited complement activation occurs on apoptotic cells. C1q recognizes "eat-me" signals on the surface of dying cells. It serves as a bridging molecule, facilitating the phagocytosis by dendritic cells or

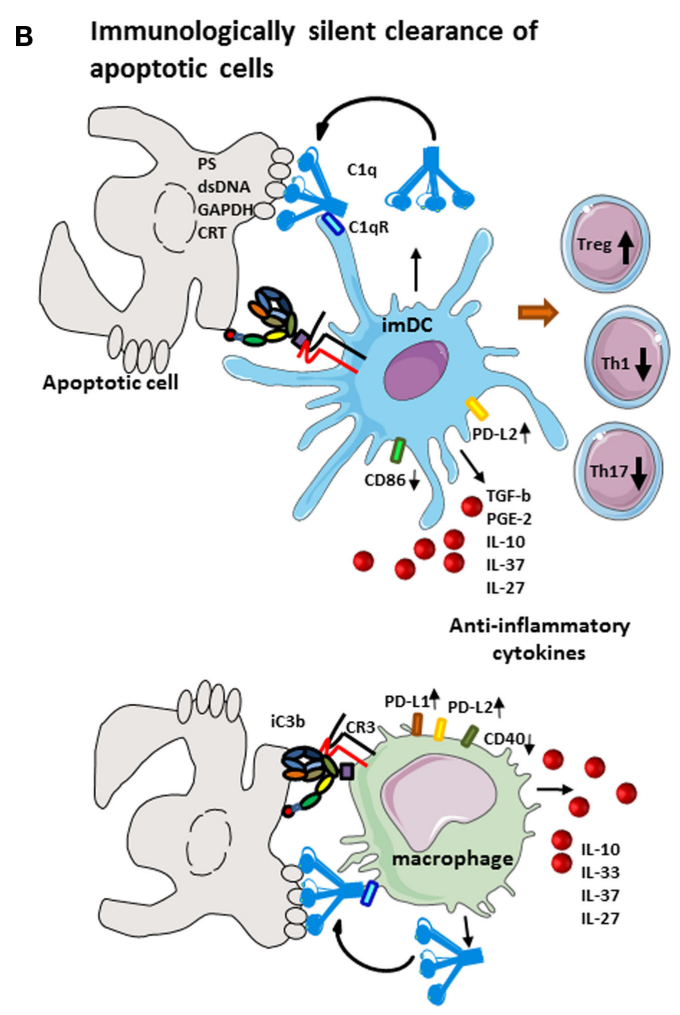

macrophages. Uptake of C1q-opsinized cargo induces an anti-inflammatory program, increased expression of immunological checkpoint molecules, and prevents up-regulation of maturation markers. iC3b on apoptotic cells interacts with $\mathrm{CR} 3$ on phagocytes and induces anti-inflammatory response. (C) Complement in human $\mathrm{T}$ cell homeostasis. Cathepsin L cleaves C3 intracellularly, generating $\mathrm{C} 3 \mathrm{a}$ and $\mathrm{C} 3 \mathrm{~b}$. C3a binds on $\mathrm{C} 3 \mathrm{aR}$, expressed in the lysosomes, and stimulates mTOR signaling pathway. This signaling is important for the cell survival in resting state. "amplification loop" of the alternative pathway (AP). Detailed description of the mechanisms of activation and regulation of the complement system are described in "Complement system part I - molecular mechanisms of activation and regulation" (1), from the same research topic of Frontiers in Immunology.

Briefly, in a healthy organism, the sentinel role is assured by the permanent activity of the AP (1 and 2). A number of complement components are produced in biologically inactive form, which allows them to co-exist in plasma, or to be produced by the same cells, without interacting with one another and inducing unnecessary and undesired complement activation. Complement components are activated in a cascade fashion after a triggering event, each step of the chain reaction, resulting in a conformational change or a cleavage of the downstream component, which becomes activated and gains the capacity to activate the subsequent component in the cascade. Spontaneous hydrolysis, called tick-over, of C3 plays an important role in the immune surveillance and AP activation (2). C3 is present in plasma at high concentrations $(\sim 1 \mathrm{mg} / \mathrm{ml})$ and a small portion of it undergoes spontaneous hydrolysis of a particular thioester bond between the side chains of two aminoacids, located in the thioester domain (TED). This hydrolysis induces a dramatic conformational change in C3 and renders it biologically active due to exposure of novel binding sites. In this new form - the $\mathrm{C} 3\left(\mathrm{H}_{2} \mathrm{O}\right)$, it recruits two other plasma molecules - factor $\mathrm{B}(\mathrm{FB})$ and factor $\mathrm{D}(\mathrm{FD})$. FD cleaves $\mathrm{C} 3\left(\mathrm{H}_{2} \mathrm{O}\right)$-bound $\mathrm{FB}$ to generate an enzymatic complex $\mathrm{C} 3\left(\mathrm{H}_{2} \mathrm{O}\right) \mathrm{Bb}$, called fluid phase $\mathrm{C} 3$ convertase. The name convertase indicates that this enzymatic complex can cleave (convert) a native C3 molecule into bioactive fragments $\mathrm{C} 3 \mathrm{a}$ (the small fragment) and C3b (the big fragment). C3a is an anaphylatoxin - a pro-inflammatory molecule, which activates the surrounding cells when reaching a threshold concentration. Upon releasing the C3 ANA domain, which becomes the C3a molecule, the remaining part $\mathrm{C} 3 \mathrm{~b}$ undergoes a dramatic conformational change, similar to that of $\mathrm{C} 3\left(\mathrm{H}_{2} \mathrm{O}\right)$. In the newly generated $\mathrm{C} 3 \mathrm{~b}$, contrary to $\mathrm{C} 3\left(\mathrm{H}_{2} \mathrm{O}\right)$, the thioester bond is not hydrolyzed but becomes transiently exposed, allowing, for a very short time, a covalent reaction with $\mathrm{OH}^{-}$or $\mathrm{NH}^{-}$groups on any molecule or cell in its immediate surroundings. If this bond is not formed, the very short-lived nascent form is hydrolyzed and inactivated in few milliseconds, leaving the inactivated $\mathrm{C} 3 \mathrm{~b}$ molecule in the fluid phase. When covalently bound to a cell, $\mathrm{C} 3 \mathrm{~b}$ has different fates depending if it is on a host cell or on a foreign surface. 


\section{Protection of the Host Cells Against Complement Attack}

The deposition of C3b is highly controlled on host cells. Host cells express complement regulatory molecules on their surface (membrane bound such as membrane cofactor protein, MCP, CD46 or complement receptor 1, CR1, CD35), or recruit plasma regulators, like factor $\mathrm{H}(\mathrm{FH})$, which bind to C3b. These proteins serve as cofactors, allowing interaction with a plasma serine protease factor I (FI), which cleaves C3b into iC3b (Figure 2A). This results in a conformational change, which suppresses the ability to interact with FB but exposes of novel binding sites in the iC3b molecule, allowing it to interact with other complement molecules. FH also blocks the binding of FB and FD to C3b, thus preventing the formation of $\mathrm{C} 3$ convertases. The overall action of all these regulators results in the prevention of complement activation on host cells. In the absence of surface regulators, such as in the case of pathogens or other foreign surface, C3b interacts with $\mathrm{FB}$ and $\mathrm{FD}$, forms $\mathrm{C} 3$ convertases, which cleave more molecules of C3 to C3a and C3b, thus fueling the amplification loop and allowing full-blown complement activation and, finally, pathogen elimination.

\section{Immunologically Silent Phagocytosis of Apoptotic Cells}

Between these two extremes (healthy cell and pathogen) remains the case of stressed and apoptotic host cells. The human body is composed to a myriad of different cells, forming a highly organized system. The proliferation, differentiation, activity, and also the death of cells in this system are tightly controlled. Programed cell death induces major cellular modifications. During a classical cell death, the cell surface undergoes many structural and molecular modification, leading to "eat-me" signals expression. Phagocytes recognize these signals and execute the degradation of apoptotic cell without mounting of an immunologic response. Among these modifications, a major one is the expression of phosphatidylserine (PS) on the external side of the cell membrane, which is normally sequestered in the inner surface of the cell membrane (3). Also, the expression level of some complement regulators (such as MCP) can be reduced. Clearance of apoptotic cells is critical for many physiological processes, including development, tissue remodeling, and maintenance of homeostasis.

The complement system plays a major role in the tolerogenic perception of apoptosis, which is in part mediated by opsonization with $\mathrm{C} 1 \mathrm{q}$ and $\mathrm{iC} 3 \mathrm{~b}$ and subsequent clearance of dying cells (4, 5) (Figure 2B). C1q, which is the recognition molecule of the $\mathrm{CP}$, is produced by macrophages and dendritic cells (DCs) and binds to a variety of ligands that can be expressed on the surface of apoptotic cells such as PS, double stranded DNA, GAPDH, or calreticulin (6-9). C1q has complex immune-modulatory effects and a failure of $\mathrm{C} 1 \mathrm{q}$ to opsonize apoptotic cells results in defective phagocytosis by monocytes (10) and activation of the DCs (11). Consistently, a quantitative or functional deficiency in C1q may be related to improper apoptotic cell clearance and autoimmunity $(12,13)$. Similar functions are described for mannose binding lectin (MBL), one of the recognition molecules of the LP (14).

C1q coated apoptotic cells suppress macrophage inflammation through induction of interleukine 10 (IL-10), IL-27, IL-33, and IL-37, inhibit inflammasome activation and increase the expression of negative regulators ASC2 and NLRP12 (15). It has recently been demonstrated that opsonization of apoptotic cells by $\mathrm{C} 1 \mathrm{q}$ induced an increase of the expression of PD-L1 and PD$\mathrm{L} 2$ and a diminution of CD40 at the surface of macrophages (16). Similar effects are observed also on dendritic cells. Presentation of self-antigens by DC in the presence of $\mathrm{Clq}$ promotes the development of regulatory $\mathrm{T}$ cells (Treg) and the production of anti-inflammatory cytokines such as TGF-b, IL-10, PGE2, IL-37, and IL-27 and thus confers tolerance. In addition, opsonization of the apoptotic cells with $\mathrm{Clq}$ induced a high expression of PDL2 and less CD86 on dendritic cells surface after phagocytosis. This "polarization" by C1q-induced decrease of T helper 1 (Th1) and Th17 and proliferation. The non-maturation of the phagocytes, which is showed by the expression of CD40 and CD86 on macrophages and dendritic cells, respectively, and by the secretion of anti-inflammatory cytokines, makes the phagocytosis immunologically silent (16). Therefore, C1q is of critical importance for the silent, non-immunogenic clearance of apoptotic cells (17) (Figure 2B).

The inactivated fragment of the central complement component $\mathrm{C} 3-\mathrm{iC} 3 \mathrm{~b}$ participates in the clearance of apoptotic cells via interaction with CR3 on monocytes, macrophages, DC, and microglial cells (18-20). iC3b opsonization and CR3-dependent phagocytosis is accompanied by a down-regulation of the proinflammatory mediator IL-12 and a lack of oxidative burst in macrophages $(21,22)$ or by a reduction in the expression of costimulatory molecules and impaired maturation of DC $(23,24)$. This confers anti-inflammatory properties and supports tolerogenic apoptotic cell clearance.

\section{Cell Homeostasis}

In the native state, different cell types secrete complement components and generate $\mathrm{C} 3 \mathrm{a}$ and $\mathrm{C} 5 \mathrm{a}$ in their microenvironment, an important fact for their viability and function. Liszewski et al. demonstrated that $\mathrm{C} 3$ activation can occur continuously within human T cells, mediated by cathepsin L (CTSL) and in a C3 convertase-independent manner (25) (Figure 2C). In resting $\mathrm{T}$ cells, this C3a binds to intracellular C3aR, expressed in lysosomes, but not on the cell surface. Intracellular C3aR signaling sustains basal mTOR activation (25), required for homeostatic cell survival (26). Of note, C3a generated outside the cell cannot restore the mTOR signaling in cells with inhibited CTSL, suggesting the importance of intracellular generated C3a (25). Upon $\mathrm{T}$ cell receptor (TCR) activation, C3aR is expressed on the cell surface and contributes to the mounting of Th1 response in concert with CD46 signaling.

Of note, the phenomenon of intracellular $\mathrm{C} 3$ cleavage seems to be species specific, because it does not operate in mice. In mice, resting $\mathrm{T}$ cells synthesize complement components constitutively, complement activation occurs in their microenvironment, and the resultant $\mathrm{C} 5 \mathrm{a}$ and $\mathrm{C} 3 \mathrm{a}$ signaling, through the $\mathrm{C} 5 \mathrm{aR}$ and $\mathrm{C} 3 \mathrm{aR}$, participates in cell viability by maintaining the level of phosphorylated AKT (PKB), a T cell activation intermediate that suppresses apoptosis (27). In the absence or after blockade of C5aR and C3aR, the expression of MHC class II and costimulatory-molecules is decreased on dendritic cells $(27,28)$. The exact contribution to 
T cells survival of the intracellular and extracellular C3a generation and $\mathrm{C} 3 \mathrm{aR}$ signaling is still not well defined. It is important to note that AKT (PKB) and mTOR belong to the same signaling cascade, which has anti-apoptotic, survival, and proliferation effects (29). The intracellular complement activation is not restricted to T cells (25), and may have an important role in the physiology of other human cell types.

\section{Complement as a First Line of Defense Against Pathogens}

\section{Direct Killing}

Pathogens are attacked by all complement pathways, but the prevalence of one or another pathway depends on the exact membrane composition. C3b generated by the spontaneous activation of the AP tag all pathogens and, when no regulator is present, the cascade and the deposition of $\mathrm{C} 3 \mathrm{~b}$ are accelerated (Figure $\mathbf{3 A}$ ). In addition, the pathogen-associated molecular patterns can be recognized by the recognition molecules of the CP and LP C1q and MBL or ficolins. C1q recognizes mostly charged patterns and can bind to more than 100 different target molecules (30), including pathogen-associated molecular patterns such as lipopolysaccharide (LPS) (31) or bacterial porins (32). MBL binds to a wide range of repeating sugar arrays normally presented by many microorganisms, including mannose structures on fungal and micrococcal surfaces, and $\mathrm{N}$-acetylglucosamine residues in cell walls of bacteria, in order to initiate neutralization of these organisms (33). C1q may bind also on natural antibodies, which due to their polyreactivity can recognize the pathogens (34). Upon target recognition, $\mathrm{C} 1 \mathrm{q}$ undergoes conformational change and activates the two serine proteases $\mathrm{C} 1 \mathrm{r}$ and $\mathrm{C} 1 \mathrm{~s}$, associated with it in the context of the $\mathrm{C} 1$ complex $(35,36)$. Despite the similarity between $\mathrm{C} 1$ and MBL/MASP complex architectures, the mechanism of activation of the CP and LP differ (37). In particular, the serine proteases of the LP, MASP-1, and 2, are associated with different MBL (or ficolin) molecules, thus requiring a juxtaposition to allow MASP-1 from one complex to activate MASP-2 from the adjacent complex $(38,39)$. However, MASP-2 alone provides about $10 \%$ to cleave its natural substrate C4 by auto-activation (40). Activated serine proteases of the $\mathrm{CP}$ and LP cleave $\mathrm{C} 4$ and $\mathrm{C} 2$ to allow formation of the $\mathrm{CP}$ C3 convertase $\mathrm{C} 4 \mathrm{~b} 2 \mathrm{a}$, which cleaves $\mathrm{C} 3$. If this convertase is not regulated, $\mathrm{C} 3$ deposition will be accelerated and

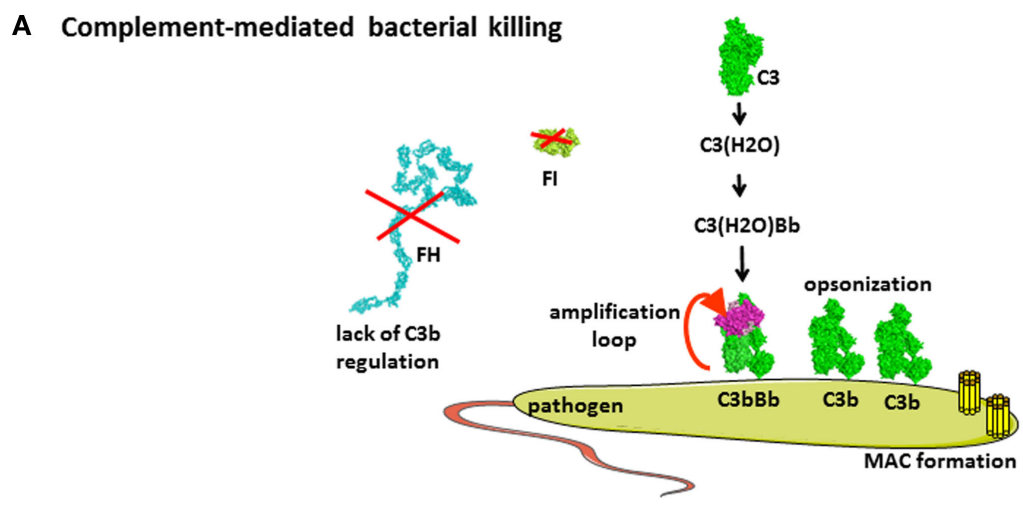

B Engulfment of C3 fragments-opsonized pathogens
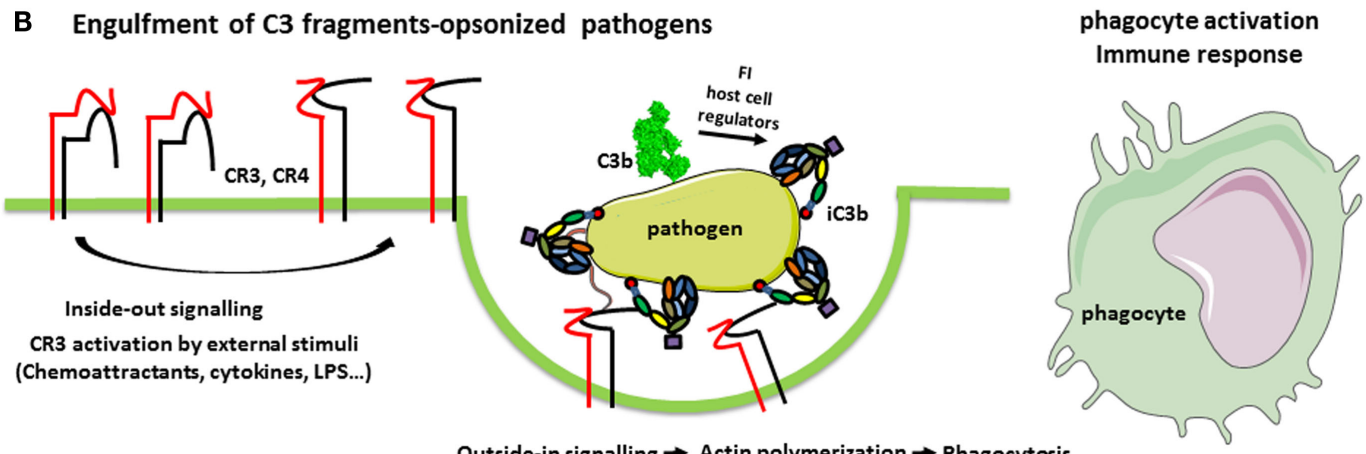

FIGURE 3 | Complement in the defense against pathogens

(A) Complement-mediated bacterial killing. C3b is deposited on any pathogen surfaces due to the constant activity of the AP. Since most pathogens do not have complement regulatory molecules, $\mathrm{C} 3 \mathrm{~b}$ is not inactivated and interacts with FB and FD to form a C3 convertase C3bBb. This enzymatic complex cleaves more C3 molecules, resulting in pathogen opsonization with C3b. Further, the cascade proceeds to a C5 convertase and MAC formation, contributing to bacterial killing. (B) Complement receptors-mediated phagocytosis of C3b and iC3b-opsonized pathogens. Extracellular stimulatory signals, which are necessary for the CR3-mediated phagocytosis, include chemoattractants (not only chemokines but also bacterial formylpeptides and C5a for neutrophils), cytokines (e.g., TNF- $\alpha$ ), and bacterial products (e.g., lipopolysaccharide). External stimuli activate the integrin CR3, (i.e., change to a conformation with high affinity for iC3b) by a Rap-1-mediated signaling. Stabilization of CR3 high-affinity conformation by its engagement with iC3b triggers a RhoA-mediated signaling, which drives the actin polymerization to engulf iC3b-coated target. Complex actin movements are then involved in the intracellular movement of the phagosome during its maturation to the phagolysosome. 
the amplification loop will be turned on. Binding of an additional $\mathrm{C} 3 \mathrm{~b}$ molecule in the immediate proximity, or most probably on the $\mathrm{C} 3$ convertase itself, modifies the specificity of the enzyme (41). It then starts to cleave C5, thus turning on a C5 convertase of the classical $(\mathrm{C} 4 \mathrm{~b} 2 \mathrm{aC} 3 \mathrm{~b})$ or alternative $(\mathrm{C} 3 \mathrm{bBbC} 3 \mathrm{~b})$ pathway. Cleavage of $\mathrm{C} 5$ gives rise to a powerful anaphylatoxin $\mathrm{C} 5 \mathrm{a}$ and to a C5b fragment, which initiates the terminal part of the cascade, common for all activation pathways.

Activation of the terminal complement pathway results in the formation of the membrane-attack complexes (MAC), which forms large, $10 \mathrm{~nm}$ wide, pores in the target membrane (42). In fact, most pathogens are able to repair MAC-induced lesions and are resistant to complement lysis by MAC, as Gram-positive bacteria (43). Nevertheless, some Gram-negative bacteria are relatively sensitive to complement killing, particularly the meningitis causing Neisseria species $(44,45)$. This is illustrated by the susceptibility of individuals, deficient in terminal complement components as well as in properdin, to recurrent meningitis. Gram-positive bacteria have a very thick cell wall, which MAC cannot penetrate, therefore being resistant to complementmediated lysis. Metabolically active nucleated cells are also resistant to lysis by complement $(46,47)$. However, increase of $\mathrm{Ca}$ flux and signal transduction have been described as the result of the insertion of multiple MAC in the membrane, inducing either apoptosis and cell killing or leading to cell proliferation depending on the cell type $(48,49)$. The molecular mechanisms of complement activation on pathogens are reviewed in detail and illustrated in Merle et al. (1).

\section{Opsonization and Phagocytosis}

The main role of complement in pathogen elimination is indirect, namely, the deposition of complement fragments on the surface of pathogen targets, so-called opsonization that allows their recognition, ingestion, and destruction by phagocytic cells, neutrophils, monocytes, and macrophages (Figure 3B). Both IgG antibodies and C3 fragments are the classical opsonins. But complement opsonization, resulting from the direct activation of the AP on pathogens surface allows their elimination by phagocytes before the mounting of an adaptive immune response and the appearance of antibodies (Figure 3). Phagocytes express specific receptors for C3 fragments, described in "Complement system part I - molecular mechanisms of activation and regulation” (1).

CR1 is a complement component molecule (CCP) domain containing molecule, involved in the control of $\mathrm{C} 3$ convertases. It is present on erythrocytes, on phagocytes, and on kidney glomerular podocytes and binds $\mathrm{C} 3 \mathrm{~b}$ and C4b. CR1 on erythrocytes plays a major role in the clearance of soluble immune complexes, by transporting them to the liver and spleen, where they are cleared by macrophages. The binding of C3b-coated targets to phagocyte CR1 is not sufficient to trigger phagocytosis, but C3b-CR1 interaction enhances the Fc $\gamma \mathrm{R}$-mediated phagocytosis of targets bearing both IgG and $\mathrm{C} 3 \mathrm{~b}$. Moreover, immune mediators that activate phagocytes, such as fibronectin (50) or LPS (51), induce the phagocytosis of targets opsonized with C3b only. However, this is probably partially mediated by CR1 in that case, since elastase, a major protease released by activated phagocytes, is able both to degrade CR1 and to cleave C3b into iC $3 b$, allowing then
iC3b-coated targets to be recognized by the efficient phagocytic receptor CR3 (52).

CR3 and CR4 are specific receptors for iC3b, among C3 fragments, able to induce the phagocytosis of $\mathrm{iC} 3 \mathrm{~b}$-coated targets (53, 54). CR3 and CR4 belong to the integrin family, involved in cell adhesion processes, due to their ability to interact, in particular, with intercellular molecule-1 (ICAM-1), present on many cells, including endothelial cells. Integrins are formed from two chains, alpha and beta bearing magnesium ions necessary for their function. CR3 (also called MAC-1, $\alpha \mathrm{M} \beta 2$ or CD11bCD18) and CR4 (p150,95, $\alpha \times \beta 2$ or CD11cCD18) form, with LFA-1 and $\alpha \mathrm{D} \beta 2$, the leukocyte-specific integrin subfamily sharing the $\beta 2$ chain (CD18). The CR3 also bear a lectin site, different from the $\mathrm{iC} 3 \mathrm{~b}$ and ICAM-1 binding site, and able to recognize microorganismderived sugar ligands. If both the lectin and the iC3b-binding sites of CR3 are engaged, the strength of the CR3-mediated phagocytic response is enhanced (55).

CR3 is present on monocytes and its expression is up-regulated upon monocyte to macrophage differentiation. Resting neutrophils express low levels of CR3 on their surface but these levels increase dramatically following cell activation, due to the externalization of large intra-granular pools of receptors. CR4 is expressed poorly on neutrophils and monocytes, but its expression increases upon monocyte differentiation to macrophage or to dendritic cells.

The cellular processes involved in the phagocytosis of IgG- or C3-opsonized targets are different. When phagocytosis is mediated primarily via CR3, the reaction is slow and pathogens gently sink into the phagocyte, by a process involving actin polymerization dependent on the small GTPase Rho (53). By contrast, the Fc $\gamma$ receptors provide a very vigorous engulfment of IgG-coated pathogens, with membrane extensions driven by small GTPases $\mathrm{Rac}$ and Cdc42. However, the CR3-mediated phagocytic response to $\mathrm{iC} 3 \mathrm{~b}$-coated targets is boosted by the participation of additional receptors such as toll-like receptors (TLRs) recognizing pathogen patterns.

Indeed, it is worth noting that CR3 and CR4 induce phagocytosis mainly in conjunction with stimuli, such as pro-inflammatory cytokines, which activate phagocytic cells (56). These stimuli induce an inside-out signaling, which switches integrins to an active conformation with a higher affinity for iC3b and ICAM-1 (53). This may represent a control mechanism to avoid unwanted responses to host cells passively coated with a few iC3b molecules resulting from the continuous low-grade activation of the AP.

Apart from CR3 and CR4, some resident macrophages such as liver Kupffer cells express CRIg, a receptor for iC3b belonging to the immunoglobulin family and able to mediate the phagocytosis of iC3b-coated pathogens (57).

The main consequence of phagocytosis is the elimination of pathogens. Internalized microorganisms are killed both by toxic reactive oxygen compounds, generated through a NADPH oxidase complex assembled at the phagosomal membrane, and by microbicidal components, such as lysozyme and proteases, present in phagocyte granules fused with the phagosome to form the phagolysosome. Finally, CR3-mediated phagocytosis results in the apoptosis of phagocytic cells, an important step of the resolution of infection and inflammation (58). 


\section{Complement in Inflammation}

\section{Anaphylatoxins and Their Receptors}

Complement anaphylatoxins $\mathrm{C} 3 \mathrm{a}$ and $\mathrm{C} 5 \mathrm{a}$ play a critical role in the modulation of immune system activity by complement. $\mathrm{C} 3 \mathrm{a}$ and $\mathrm{C} 5 \mathrm{a}$ are the small fragments released after cleavage of C3 and C5 by the C3 and C5 convertases of the classical and APs. They contribute to the inflammation and activate immune cells and non-myeloid cells, which express G-protein coupled anaphylatoxin receptors $\mathrm{C} 3 \mathrm{aR}$ and $\mathrm{C} 5 \mathrm{aR}(59,60)$ (Figure 4). Anaphylatoxins stimulate inflammation by inducing an oxidative burst in macrophages (61), eosinophils (62), and neutrophils (63). Moreover, C3a and C5a induce histamine production by basophils (64) and mast cells (65), resulting in vasodilatation. Even if pro-inflammatory effects of $\mathrm{C} 3 \mathrm{a}$ are not in question, studies highlight the anti-inflammatory role of $\mathrm{C} 3 \mathrm{a}$ in different contexts (66). Neutrophil migration and degranulation are prevented by the presence of $\mathrm{C} 3 \mathrm{a}$, whether others granulocytes are activated by this anaphylatoxin $(63,67,68)$. Thus, this suggests an antiinflammatory role in acute phase of inflammation, and in cases of ischemia-reperfusion injury and in sepsis mouse models $(69,70)$.

The activation product of $\mathrm{C} 4, \mathrm{C} 4 \mathrm{a}$, seems also to have a functional activity on macrophages and monocytes $(71,72)$.
Nevertheless, no C4a receptor has been reported, making it difficult to ascertain the physiological role of C4a (73). More studies are needed to understand whether $\mathrm{C} 4 \mathrm{a}$ is an anapylatoxin and what is its mode of action.

In plasma, C3a and C5a are quickly converted by carboxypeptidase $\mathrm{N}$ and carboxypeptidase $\mathrm{B}$ into C3a-desArg and C5adesArg, by cleavage of the C-terminal arginine (74-76). Recent study determined a central role of $\mathrm{C} 3 \mathrm{a}$ in carboxypeptidase $\mathrm{B} 2$ (CBP2) negative mice, which are unable to convert C3a and C5a to C3a-desArg and C5a desArg (77). Using a treatment with blocking antibody against $\mathrm{C} 3 \mathrm{aR}$ or $\mathrm{C} 5 \mathrm{aR}$, mice with only a functional $\mathrm{C} 3 \mathrm{a} / \mathrm{C} 3 \mathrm{aR}$ axis present better survival after sepsis induction, whereas mice with only a functional $\mathrm{C} 5 \mathrm{a} / \mathrm{C} 5 \mathrm{aR}$ axis present a less survival compare to wild-type mice. These data demonstrate two opposite effects between C3a and C5a, highlighting the complex role of $\mathrm{C} 3$ a depending on the context. Another particularity of $\mathrm{C} 3 \mathrm{a}$ and $\mathrm{C} 5 \mathrm{a}$ is that $\mathrm{C} 3 \mathrm{a}$-desArg loses its ability to bind to C3aR and C5a-desArg has 90\% weaker pro-inflammatory activity compared to $\mathrm{C} 5 \mathrm{a}$, as shown in human astrocyte model (78). By contrast, murine $\mathrm{C} 5 \mathrm{a}$-desArg is as potent as murine $\mathrm{C} 5 \mathrm{a}$ upon binding to $\mathrm{C} 5 \mathrm{aR}$ on murine cells (79). These inter-species differences have to be taken into account when in vivo experiments are analyzed.

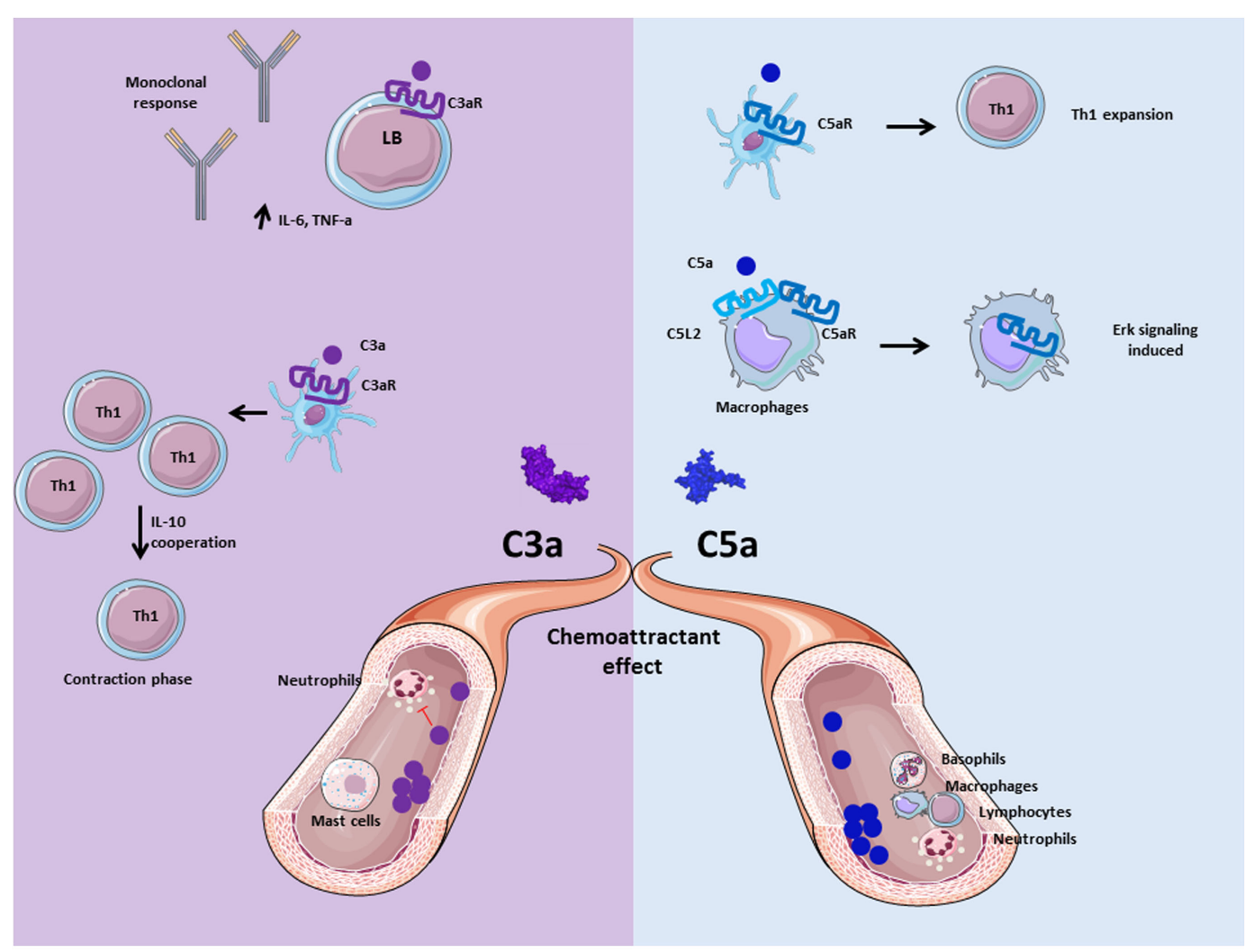

FIGURE 4 | Role of anaphylatoxins C3a and C5a. Anaphylatoxins C3a and C5a participate in inflammation by interacting and activating immune cells via $\mathrm{C} 3 \mathrm{aR}$ and $\mathrm{C5aR}$, respectively. C3a is implicated in the adaptive immunity by inducing monoclonal response from $\mathrm{B}$ cells and up-regulation of proinflammatory cytokines. Moreover, C3a facilitates the contraction phase of $\mathrm{T}$ cells by increasing IL-10 synthesis. C5a is implicated in Th1 expansion to improve adaptive immunity response, and allows C5aR internalization in presence of C5L2 to induce ERK signalization and pro-inflammatory effect of macrophages. Both are chemoattractant molecule, and allow mast cells migration for $\mathrm{C} 3 \mathrm{a}$, basophils, macrophages, neutrophils, and lymphocytes recruitment for C5a at the inflammatory site. Nevertheless, $\mathrm{C} 3 \mathrm{a}$ has an anti-inflammatory effect on neutrophils by inhibiting their degranulation and recruitment. 
Human $C 3 a$ specifically binds its receptor $C 3 a R$ (80), whereas C3a-desArg and C5a cannot bind to this receptor (81). C3aR belongs to the G-protein coupled receptor (GPCR) family with seven transmembrane domains. C3a binding leads to transduction of intracellular signals via heterotrimeric G-proteins and phosphorylation of $\mathrm{PI} 3 \mathrm{~K}, \mathrm{Akt}$, and mitogen-activated protein kinase (MAPK), leading to chemokine synthesis in human (82). Moreover, in human mast cells, C3a plays a role of chemoattractant molecule and can play an important role in hypersensitivity and inflammatory process (83). In case of chronic inflammation, C3a has pro-inflammatory activity and contributes to disease progression (60). In human monocytes and monocyte-derived macrophages, C3aR and TLR-4 costimulation induce the production of pro-inflammatory mediators, such as IL-1 $\beta$, tumor necrosis factor alpha (TNF- $\alpha)$, IL-6, and PGE2 $(84,85)$. Contrary to these pro-inflammatory functions, in acute inflammation conditions C3a prevents mobilization and degranulation of neutrophils $(66,68)$. The difference in the response of inflamed tissues to C3a, between the acute and chronic phases of inflammation, may well be due to the differing cell types involved (e.g., neutrophils versus monocyte/macrophages) (66).

C3a modulates also the responses of the cells of the adaptive immunity. Human $\mathrm{C} 3 \mathrm{a}$ has been described to regulate $\mathrm{B}$ cell function by suppressing the polyclonal immune response, IL-6 and TNF $\alpha$ release, in a dose-dependent manner (86). Mice C3aR signaling on DCs is important for the generation of Th1 cells (28, 87). A lack of C $3 a R$ activation on DC induces a Th2 polarization and favors the emergence of Treg. C3aR is also expressed on adaptive immune cells, such as $\mathrm{T}$ lymphocytes. Indeed, the importance of $\mathrm{C} 3 \mathrm{aR}$ and $\mathrm{C} 5 \mathrm{aR}$ expression for Th1 induction has been demonstrated in mice $(27,88,89)$. Moreover, C3 deficiency induced a decreased expression, on T cells, of the $\alpha$ and $\beta$ chains of the IL2 receptor. This may explain the aberrant Th1 response observed in patients with C3 deficiency. C3a also participates in the contraction phase of Th1 by regulating IL-10 expression (88).

$\mathrm{C} 3 \mathrm{aR}$ is expressed not only by the immune cells but also by endothelial and epithelial cells. Stimulation of C3aR on endothelial cells induces a rapid mobilization of intracellular granules, Weibel-Palade bodies, containing von Willebrand factor and P-selectin. Hence, the cell acquire a pro-inflammatory and prothrombotic phenotype, since P-selectin helps the recruitment of leukocytes via binding to PSGL-1 (90) and von Willebrand factor mediates platelet adhesion (91). Moreover, human and mouse $\mathrm{P}$-selectin binds to $\mathrm{C} 3 \mathrm{~b}$ on cell surfaces and serves as a platform for the formation of $\mathrm{C} 3$ convertases and the activation of the AP $(92,93)$. C3a activation of endothelial cells thus forms an amplification loop of complement activation, implicated in microvascular thrombosis, including in a mouse model of Shiga-toxin (Stx2)/LPS induced hemolytic uremic syndrome (HUS) (93).

Human and mouse $C 5 a$ bind to $C 5 a R$, which also belongs also to the GPCR family (94). C5aR stimulation induces downstream effect such as activation of PI3K- $\gamma(95,96)$, phospholipase C $\beta 2$ (97), phospholipase D (98), and Raf-1/B-Raf-mediated activation of MEK-1 (99). C5a is known to be a powerful chemoattractant molecule and plays a critical role in the inflammatory response by recruiting immune cells such as macrophages (100), neutrophils (101), basophils (102), and myeloid-derived suppressor cells (MDSCs) (103). Human C5a also recruits adaptive immune cells, such as T cells, which express constitutively C5aR on their surface (104). Human B cells express C5aR but respond to C5a only in case of activation (105). In a CD55 $5^{-1-}$ mouse model, it has been demonstrated that C5a production by APC is essential for differentiation of $\mathrm{T}$ cell in Th1 effector cells (106). Indeed, addition of $\mathrm{C} 5 \mathrm{a}$ on $\mathrm{CD} 80^{-1-}, \mathrm{CD} 86^{-1-}$, and $\mathrm{CD} 40^{-1-}$ APC restored $\mathrm{T}$ cell activation, providing a link between GPCR, costimulation signals via CD28 and T cell survival (27). The axis $\mathrm{C} 5 \mathrm{a} / \mathrm{C} 5 \mathrm{aR}$ appears to have a crucial role in sepsis, based on the observation that the inhibition of $\mathrm{C} 5 \mathrm{a} / \mathrm{C} 5 \mathrm{aR}$ interaction decreased the mortality in a rat model (107). Another function of C5a is to induce vascular endothelial growth factor (VEGF) expression and to promote angiogenesis in a human retinal model (108). In a model of enteric infection, $\mathrm{C} 5 \mathrm{a}$ is generated thanks to the stabilization of the AP C3 convertase by properdin and leads to IL6 release from colonic epithelial cells (109). Then, IL-6 regulates inflammation induced by bacteria. In properdin deficient mice, the C5a-dependent IL-6 production is impaired, aggravating the infection. This provides evidences of the implication of C5a in the defense against bacteria-triggered epithelial injury.

$C 3 a, C 5 a$, and $C 5 a$ desArg are also able to bind C5L2. In human, C3a-desArg is able to bind C5L2 and regulates triglyceride synthesis rate (110). C5a has a lower affinity for C5L2, as compared to C5a desArg in human basophil cell lineage (111). As C5aand C3a-receptors, C5L2 is composed by seven transmembrane domains but it is not coupled with G protein (112). Previous work on human neutrophil determined a role of C5L2 as a negative regulator of anaphylatoxin receptor activity after activation and interaction with $\beta$-arrestin, this was confirmed in mouse model $(113,114)$. However, its role remains unclear. C5L2 has been described as an anti-inflammatory receptor, because C5L2 ${ }^{-1-}$ mice have increased production of pro-inflammatory cytokines IL-6 and TNF- $\alpha$ (115). Nevertheless, deficiency of C5L2 on macrophages, neutrophils, and fibroblasts decreased their proinflammatory capacity in vitro. C5L2 is also essential for the C5amediated cell infiltration in in vivo, in a mouse model, suggesting a role of positive modulator of C5a-induced responses (67).

C5L2 expression in human atherosclerosis lesions is correlated with an increase of IL- $1 \beta$ and TNF- $\alpha$ release, supporting the pro-inflammatory effect of C5L2 (116). It has recently been reported that human $\mathrm{C} 5 \mathrm{~L} 2$ and $\mathrm{C} 5 \mathrm{aR}$ are able to form a heterodimer (117). This complex induces internalization of C5aR upon C5a binding and promotes ERK and MEK signaling in a mouse model of acute experimental colitis (118). This internalization of GPCR has already been demonstrated in in vitro assays as essential for the induction of the late stage of ERK signaling $(119,120)$.

\section{Crosstalk Between C3aR and C5aR Signaling Pathways with Toll-Like Receptor Signaling}

$\mathrm{C} 3 \mathrm{a}$ and $\mathrm{C} 5 \mathrm{a}$ are able to induce potent inflammatory pathways via their receptors $\mathrm{C} 3 \mathrm{aR}$ and $\mathrm{C} 5 \mathrm{aR}$. The implication of intermediates such as NF-kB, MAPK, and c-Jun N-terminal kinase (JNK) in their transduction pathways suggests a potential crosstalk with other pathways, such as those of TLRs. Indeed, complement is involved in TLR-induced inflammation (121) (Figure 5). 


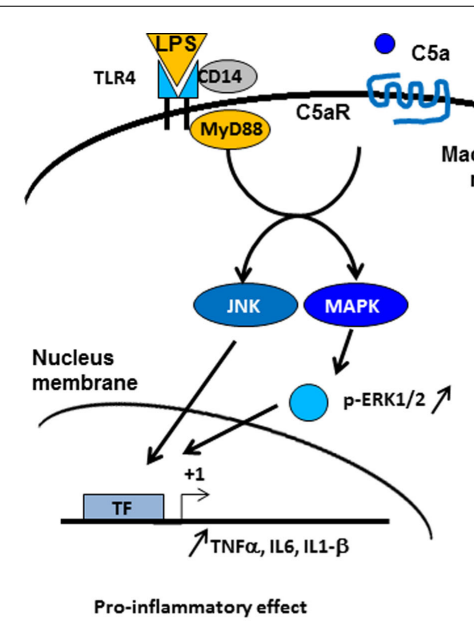

FIGURE 5 | Crosstalk between complement and TLR pathways. C5a/C5aR signaling pathway can cooperate with TLR-4 activation by LPS on macrophages. Intermediate signaling pathways JNK and MAPK are activated and thus lead to pro-inflammatory effect by TNF- $\alpha$, IL6, and IL1- $\beta$ synthesis. On dendritic cells (DCs), TLR- 4 and C5aR
Co-activation of MyD88-dependent TLRs (TLR-2, TLR-4, and TLR-9) and complement in CD55 ${ }^{-1-}$ knockout mice increased plasma inflammatory cytokines such as IL-6, TNF- $\alpha$, and IL1beta. Moreover, complement activation by the fluid phase cobra venom factor (CVF) synergizes with LPS to cause a dramatic increase of IL- 6 production. These results suggest a strong interaction between TLRs and complement signaling in vivo to promote inflammation and modulate adaptive immunity (121). Complement may interact with TLR signaling by C3aR and C5aR, because of the involvement of MAPK, extracellular signal-regulated kinase (ERK1/2), and the JNK, but not p38 MAPK (121). TLR2 also crosstalks with CR3, since TLR2 can transactivate CR3 via PI3K by an inside-out signal (122). In turn, CR3 can regulate TLR2 signalization by recruiting TIRAP and facilitating the recruitment of MyD88 signaling adaptor to initiate TLR signaling (123). Several studies have shown a crosstalk between complement and TLR-4. It is known that TLR-4 activation by LPS can induce C5aR up-regulation on hepatocytes mediated by IL-6 (124). Another, immune-modulatory function of $\mathrm{C} 5 \mathrm{a}$ is to reduce the production of IL-12 family cytokines by mouse inflammatory macrophages stimulated by TLR-4 ligands (125). In turn, this resulted in regulation of Th1 cells polarization and a limitation of their expansion. A synergy between C5a and TLR ligands on mouse DC stimulation was found upon stimulation of these cells with a fusion protein composed of $\mathrm{C} 5 \mathrm{a}$ and an endogenous ligand for TLR-4 (extra domain A) and an antigen (126). This induced strong antigen-specific $\mathrm{T}$ cell responses in vivo, without production of immunosuppressive molecules. In humans, the C5a-mediated immature DC stimulation appears more complex. C5a increases the cytokines production in immature DCs, but upon TLR-4 stimulation, C5a inhibits the production of IL-12, IL-23, and $\mathrm{TNF} \alpha$, thus having an anti-inflammatory role (127). These results emphasize that the effects of anaphylatoxins on immune response depend on the crosstalk not only with TLRs but also with other receptors.

\section{Complement and Adaptive Immunity}

Discoveries over five decades have shown that the complement system plays an important role not only in the inflammation but also in the adaptive immunity.

\section{The Complement System and Its Interplay with B Cells}

The relationship between complement and B cells has already been demonstrated 40 years ago in vitro and using in vivo models. C3 plays important role in antibody generation by B cells (Figure 6). In case of $\mathrm{C} 3$ depletion [by a structural analog of $\mathrm{C} 3$ from snake venom (CVF), which is capable to bind to FB and to activate complement in fluid phase], the humoral immunity toward certain thymus-dependent antigens and the lymphocyte cooperation was impaired $(128,129)$. These and other early studies demonstrated that complement binds and localizes foreign antigens within sites where the lymphocytes response takes place. $B$ cells express complement receptor CR2 (CD21), which interacts with $\mathrm{C} 3 \mathrm{~d}$ and $\mathrm{iC} 3 \mathrm{~b}$ on the surface of the antigen and forms also a co-receptor complex with CD19 and CD81 (130). Thus, the complex $\mathrm{C} 3 \mathrm{~d}: \mathrm{CR} 2$ induces an increase of $\mathrm{B}$ cell receptor (BCR) signaling in the presence of $\mathrm{C} 3 \mathrm{~d}$-opsonized antigen on $\mathrm{B}$ cell surface (131). In vivo, C3 is required for the induction and maintenance of memory cells of the $\mathrm{B}$ cell lineage within the microenvironment of germinal centers (GCs), where B cells encounter antigen-antibody-C3 complexes on the surfaces of follicular dendritic cells (FDCs) (132). When C3d-opsonized antigen 


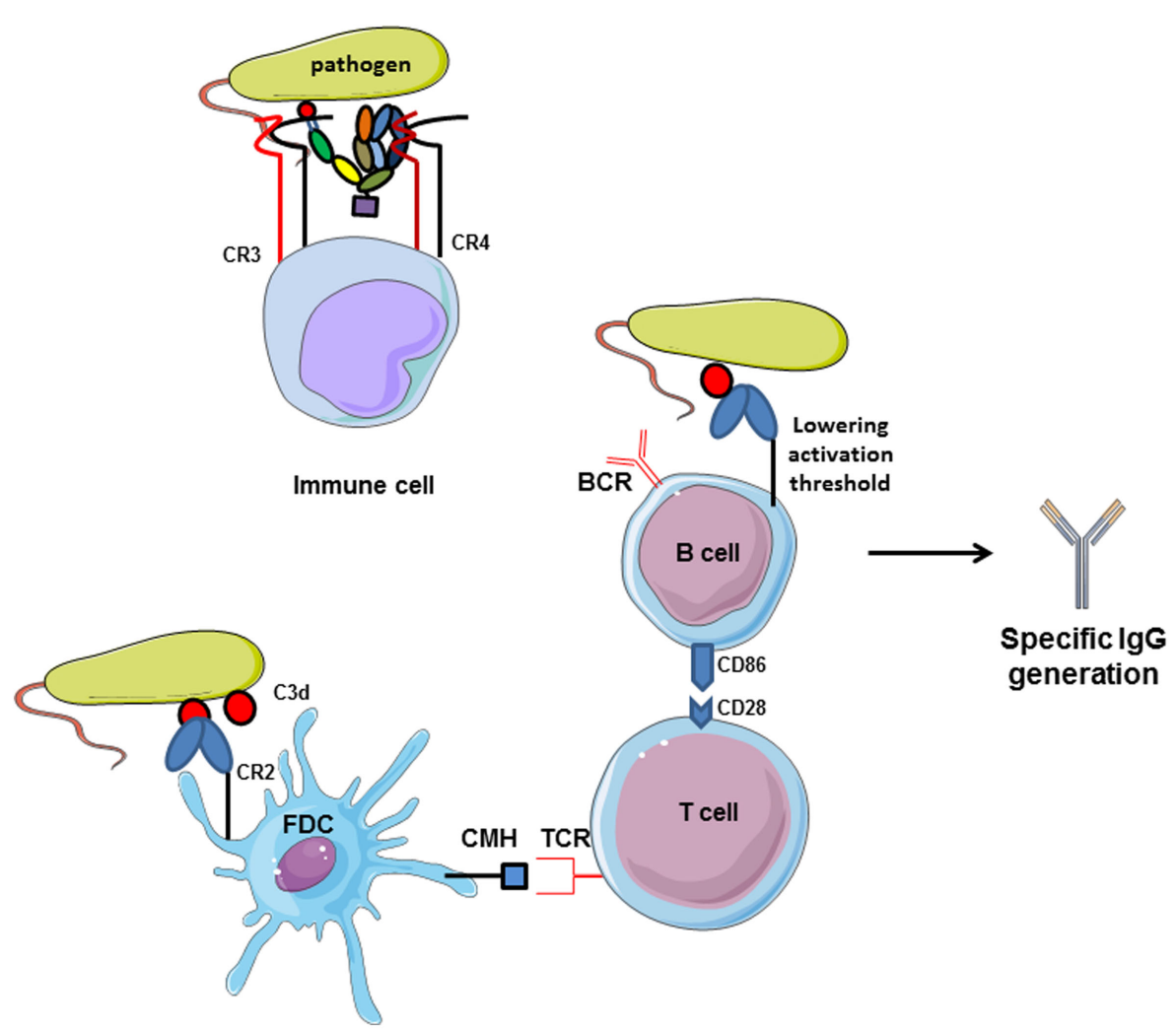

FIGURE 6 | Complement receptors implication in adaptive immunity. CR2 activation by interaction with C3d-opsonized antigen on follicular dendritic cells increases $\mathrm{CMH}$ expression and allows antigen presentation to TCR. Then, costimulatory molecules are expressed and T lymphocytes help in memory B cells maturation in germinal centers. Moreover, C3d/CR2 interaction lowers the activation threshold of B cells and increases BCR signaling activity. Cumulated, $\mathrm{C} 3 \mathrm{~d} / \mathrm{CR} 2$ interaction induces specific IgG generation by B cells, and C3d works as a natural adjuvant. CR3 and CR4, expressed on immune cells. binds to CR2 on FDCs, they can present the antigen in the GC and induce effector and memory B cells (133). This underlines the importance of CR2 expression on FDCs and B cell surface for the generation of antigen-specific IgG. C3d serves as a molecular adjuvant by lowering the threshold for $\mathrm{B}$ cell activation by 1000 to 10,000 times (134).

The human complement regulator of the $\mathrm{CP} C 4 \mathrm{~b}$ binding protein $(\mathrm{C} 4 \mathrm{BP})$ has functions extending beyond the dissociation of the classical $\mathrm{C} 3$ convertase and serving as cofactor for FI for $\mathrm{C} 4 \mathrm{~b}$ inactivation. It binds directly to the costimulatory protein $\mathrm{CD} 40$ on human $\mathrm{B}$ cells at a site that differs from that used by the CD40 ligand. C4BP induces proliferation, the up-regulation of CD54 and CD86 expressions, and IL4-dependent IgE isotype switching in normal B cells. These observations suggest that C4BP is an activating ligand for CD40 and establish another interface between complement and B cell activation (135).

The auto-reactivity of $\mathrm{B}$ cell is also tightly regulated by complement. $\mathrm{C} 4$ has been demonstrated to be essential to maintain peripheral B cell tolerance (136). Deficiency in C4 promotes the emergence of autoreactive $\mathrm{B}$ cells during the maturation in the GCs. These results could be explained by a lack in the clearance of apoptotic cells in GCs that leads to an impairment in host antigen presentation by APC, essential for the education and the peripheral B cell tolerance.
The complement system can contribute to autoimmune diseases by decreasing the threshold for $\mathrm{B}$ cell activation. For example, in a collagen-induced arthritis (CIA) mouse model, C3 depletion delays and decreases severity of the disease (137). Complement via C3d plays a key role in B cell function, and C3d antigen can break anergy in autoreactive B cells (138). Complement can modify the antigen-specific $B$ cell response in experimental autoimmune encephalomyelitis (EAE) and possibly in multiple sclerosis (MS). In EAE mouse model, consumption of complement, using CVF, significantly attenuates clinical and histological EAE (139). The authors suggest that complement breaks the anergy of autoreactive B cells, leading to autoantigen-specific IgG production, while the total IgG response remained unaffected.

\section{The Complement System and Its Interplay with T Cells}

The importance of complement for the survival of resting $\mathrm{T}$ cells has been described above. Upon infection with a pathogen, $\mathrm{T}$ cell proliferation and differentiation are controlled by APC and their microenvironment. Complement is able to polarize $\mathrm{T}$ cells and participates to the induction and effector phase, as well as to the contraction phase of the $\mathrm{T}$ cell response (140-142). In fact, during inflammation, anaphylatoxins $\mathrm{C} 3 \mathrm{a}$ and $\mathrm{C} 5 \mathrm{a}$ are able to bind their corresponding receptors expressed on the $\mathrm{T}$ cells and APC surface, leading to cytokine production by these cells (27) 


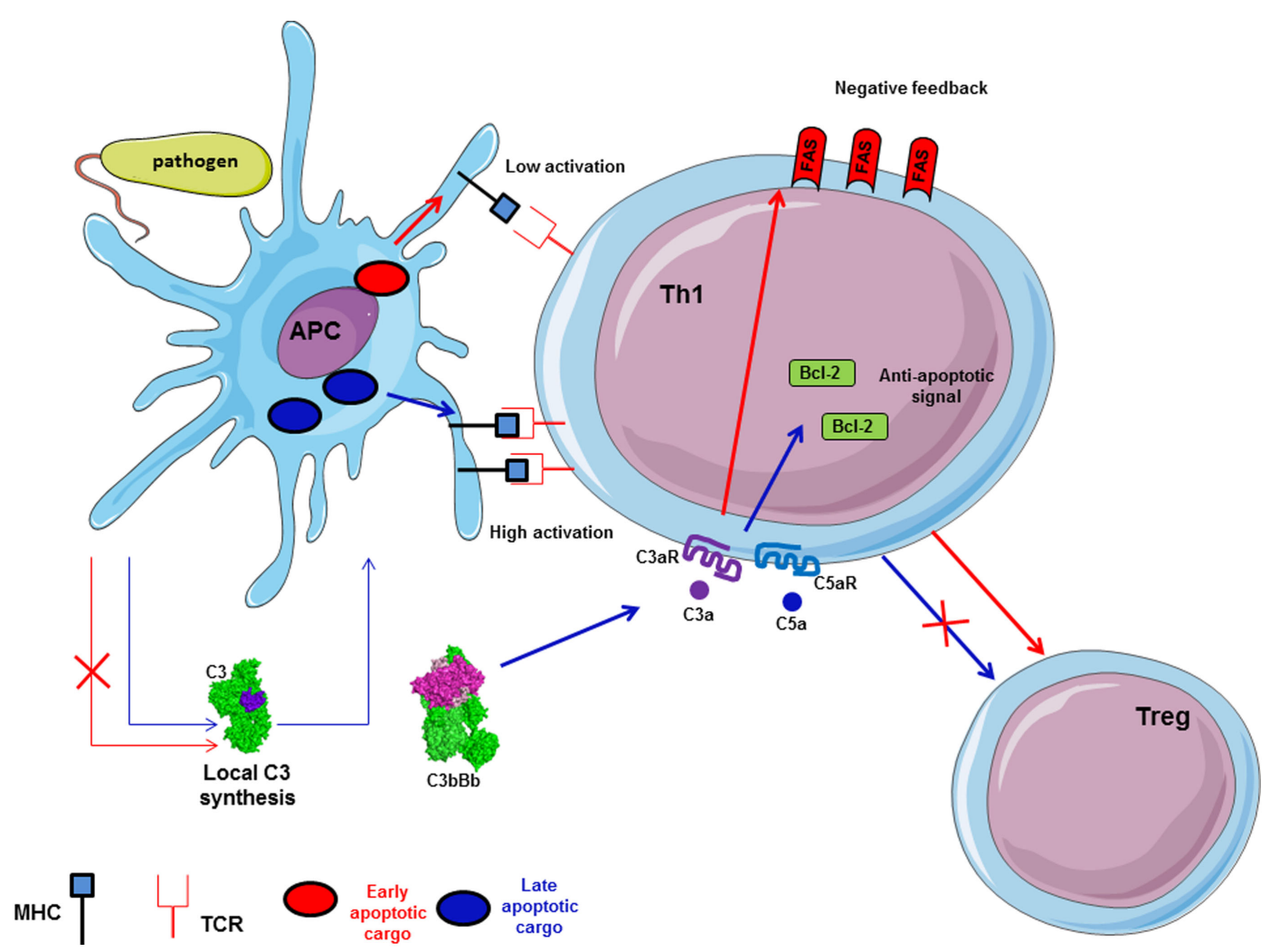

FIGURE 7 | Local synthesis of C3 by antigen presenting cells (APC) is implicated in antigen-specific $\mathrm{T}$ cell response. C3 synthesis by APC in case of pathogen internalization induces late apoptotic cargo and allows high expression of MHC on APC surface. Thus, it participates in antigen-specific $T$ cell proliferation and Th1
(Figure 7). Local C3 synthesis by DC is necessary to induce T cell activation and Th1 response (28). C3 deficiency was shown to accelerate the fusion of the apoptotic cargo with lysosomes and led to impaired antigen-specific $\mathrm{T}$ cell proliferation in vitro and in vivo (143). Moreover, C3a/C3aR is responsible for up-regulation of the anti-apoptotic $\mathrm{Bcl} 2$ and down-regulation of the pro-apoptotic molecule FAS during infection on myeloid and lymphoid cells, inducing immune cells survival and proliferation (144). The absence of $\mathrm{C} 3 \mathrm{aR}$ and $\mathrm{C} 5 \mathrm{aR}$ stimulation during $\mathrm{T}$ cell activation induces Treg development $(145,146)$. Thus, C3-deficient patients, who cannot produce $\mathrm{C} 3 \mathrm{a}$ and $\mathrm{C} 3 \mathrm{~b}$, present a lack of $\mathrm{Th} 1$ response whereas Th2 response remains normal $(147,148)$.

The complement regulator CD46 plays an important role in the regulation of T cells (149) (Figure 8). CD46 has different isoforms affecting its cytoplasmic tail and resulting from alternative splicing. Different isoforms are expressed in different organs. CD46 engagement on $\mathrm{CD}^{+}{ }^{+} \mathrm{T}$ cells promotes the effector potential of Th1 cells (150). As IL-2 accumulates, it switches cells toward a regulatory phenotype, attenuating IL-2 production and upregulating IL-10. The interaction of the CD46 cytoplasmic tail with the serine-threonine kinase SPAK plays an important role in this process. The $\gamma \delta$ T cells express an alternative CD46 isoform and thus are unable to switch from IL2 to IL10 production. The Treg express different CD46 cytoplasmic tails, as compared to Th1 cells. generation. Local $\mathrm{C} 3$ and $\mathrm{C} 5$ generate $\mathrm{C} 3 \mathrm{a}$ and $\mathrm{C} 5 \mathrm{a}$, which induce up-regulation of $\mathrm{Bcl}-2$ and down-regulation of FAS expression via $\mathrm{C} 3 \mathrm{aR}$ and $\mathrm{C} 5 \mathrm{aR}$ to facilitate $\mathrm{T}$ cell proliferation. Moreover, $\mathrm{C} 3 \mathrm{a} / \mathrm{C} 3 \mathrm{aR}$ and $\mathrm{C} 5 \mathrm{a} / \mathrm{C} 5 \mathrm{aR}$ signaling pathways activation promotes Th1 generation and avoid Treg differentiation.
Therefore, CD46 uses distinct mechanisms to regulate different $\mathrm{T}$ cell subsets during an immune response. Recently, the Notch family member Jagged1, which is expressed on T cells, has been identified as a new natural ligand of CD46 (147). Jagged1 binds Notch-1 and this interaction is responsible for cellular activation and proliferation. The cis interaction (on the same cell) of CD46 and Jagged 1 leads to a competition with Notch, thus controlling the homeostasis of naive $\mathrm{T}$ cells and inhibiting their activation. In the case of TCR stimulation, CD46 is down-regulated, which allows Notch-1 and Jagged 1 to bind in cis and in trans (from two different cells). This induces Th1 proliferation and polarization, leading to IFN- $\gamma$ and IL2 induction. Interestingly, CD46-deficient patients are unable to produce IFN- $\gamma$ and have a lack of Th1 response, whereas Th2 response remains normal. Taken together, these results suggest that the expression of CD46 is necessary to induce a Th1 response. Then, CD46 plays a negative feedback when proliferation leads to $\mathrm{T}$ cell/ $\mathrm{T}$ cell contact limiting the expansion of Th1 cells and allows a contraction phase. The binding site for Jagged 1 on CD46 has been mapped to the first two CCP domains (147). There is no overlap between this binding site and the $\mathrm{C} 3 \mathrm{~b}$ binding site, which is located in the CCP3 and 4.

CD55 (decay accelerating factor, DAF) also plays a role in the establishment of the adaptive immune response. In addition to control complement activation, experiments on CD55 deficient 


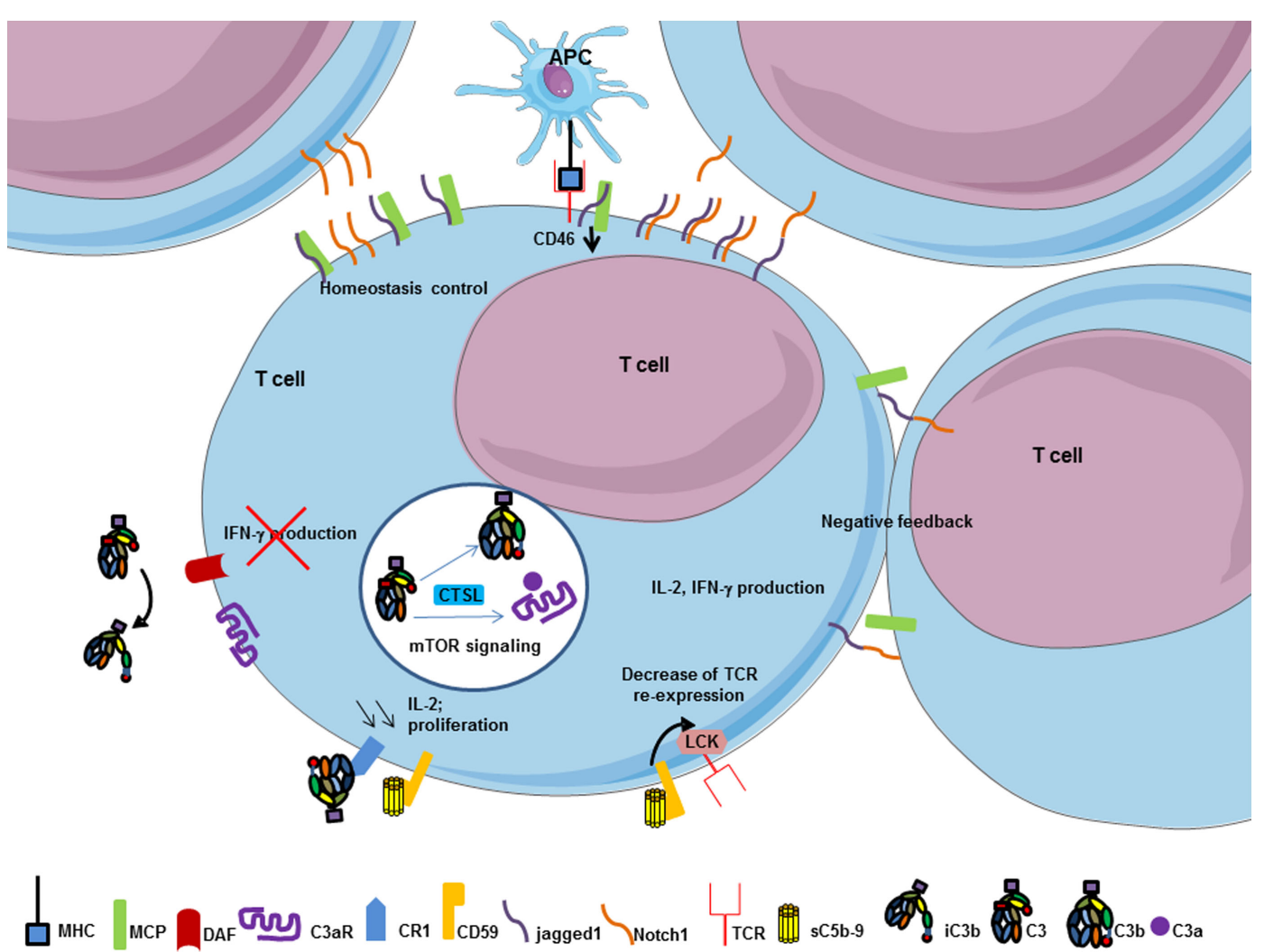

FIGURE $8 \mid \mathrm{T}$ cell response is modulated by complement components. $\mathrm{MHC} / \mathrm{TCR}$ interaction between APC and T cell decrease CD46 expression on T cell and allows cis interaction between jagged 1 and Notch-1 on T cell surface to promote $\mathrm{T}$ cell proliferation, IL-2, and IFN- $\gamma$ production. Thereafter, trans interaction between jagged 1 and Notch-1, and CD46 work as negative feedback to control T cell homeostasis. Soluble C5b-9 and CR1 regulate T cell activation. Interaction between soluble form of C5b-9 and its specific inhibitor
CD59 on T cells decrease TCR re-expression after its internalization to limit T cell activation by transmitting a signal via Lck. CR1 activation by iC3b decreases IL-2 synthesis and proliferation of $T$ cell to promote a negative feedback of $T$ cell activation. CD55 engagement on T cells negatively regulates Th1 induction cells by inhibiting IFN- $\gamma$ production. Intracellular C3 in T cell is cleaved by CTSL and promotes $\mathrm{C} 3 \mathrm{~b}$ and $\mathrm{C} 3 \mathrm{a}$ intracellular generation. Interaction between $\mathrm{C} 3 \mathrm{a}$ and C3aR induces mTOR signaling and survival signal of the immune cell. mice showed an enhanced Th1 response with a hypersecretion of IFN- $\gamma(151,152)$. This may be explained by the overactivation of complement leading to strong local anaphylatoxin production (153).

CD35 and CD59 also participate in T cell regulation. Recent study showed that CD59 is able to modulate $\mathrm{T}$ cell activation by transmitting a signal via Lck to TCR/CD3 $\zeta$. A knock-down of Lck accelerated the re-expression of CD3 at the cell surface (154). Engagement of CD35 (CR1) on T cells reduces their rate of proliferation and IL-2 secretion (155). Reduction of the expression of CD46 on activated T cells may lead to local complement overactivation, thus generating larger amount of $\mathrm{C} 3 \mathrm{~b}, \mathrm{iC} 3 \mathrm{~b}$, and C5b-9. Therefore, binding of $\mathrm{C} 3 \mathrm{~b}$ and $\mathrm{iC} 3 \mathrm{~b}$ to CD35 and C5b-9 to $\mathrm{CD} 59$ could contribute to the negative feedback controlling Th1 expansion (149).

In addition, intracellular mechanisms of sensing C3bopsonized pathogens have recently been described (156). Pathogens that cross the cell membrane, with covalently attached complement $\mathrm{C} 3$ on their surface, activate mitochondrial antiviral signaling. This mechanism would represent an autonomous immunity of the cells against non-enveloped viruses and cytosolic bacteria, by inducing signaling pathways, such as NF-kB,
IRF3/5/7, and AP-1, leading to pro-inflammatory cytokines production (156).

All these examples illustrate the importance of complement for the mounting of a successful immune response. Therefore, this cascade should not only be considered simply as a humoral factor, mediating innate immunity and inflammation, but also as a potent regulator of cells functions in the adaptive immunity.

\section{Strategies of the Pathogens to Evade the Complement System}

Complement system works as a first line of defense and allows in many cases to avoid infections. Nevertheless, the evolution of the pathogens resulted in elaboration of evasion strategies against complement attack. These mechanisms of complement evasion can be classified in different groups (157) (Figure 9).

\section{Binding of Host Complement Regulators}

Binding of host complement regulators on their membrane allows pathogens to inactivate complement. Bacteria, viruses, fungi, and parasites have been shown to bind high levels of efficient complement regulators such as $\mathrm{FH}$, factor H-like 1 (CFHL-1), and C4 


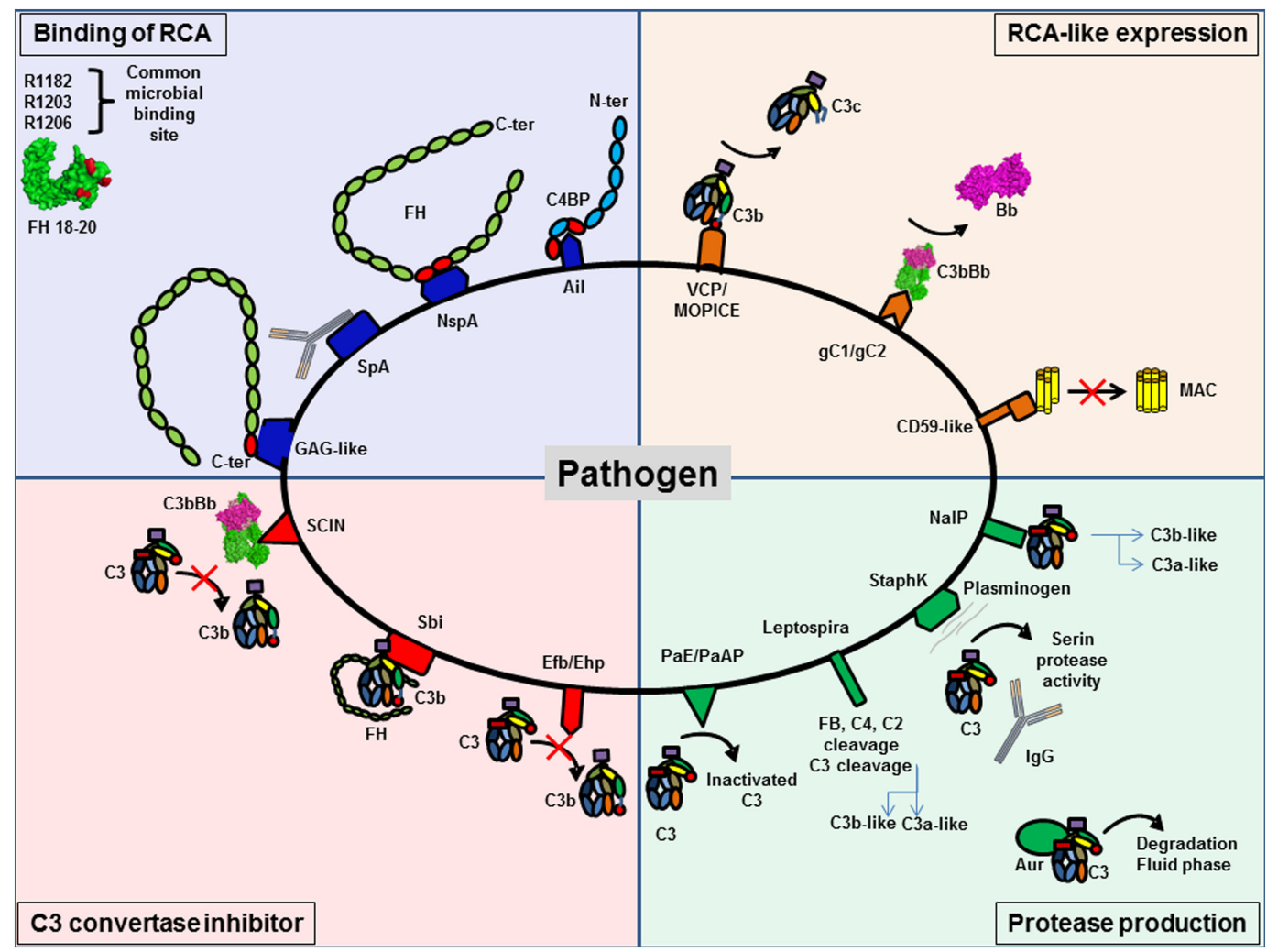

FIGURE 9 | Pathogens are able to protect themselves from complement activation. Pathogens have developed different strategies to inhibit complement activation. They can be classified in four different groups. Several pathogens are able to bind regulators of complement activation (RCA), such as FH and C4BP, to decrease $\mathrm{C} 3$ deposition. binding protein (C4BP) (158). Recruitment of these regulators can accelerate the decay of the $\mathrm{C} 3$ convertase and provide cofactors for FI, which cleaves $\mathrm{C} 4 \mathrm{~b}$ and $\mathrm{C} 3 \mathrm{~b}$, thus protecting the pathogen against complement attack.

To bind fluid phase complement regulators, pathogens express specific molecular platforms with high affinity, such as PorA in Neisseria meningitidis (159), filamentous hemagglutinin in Bordetella pertussis (160), Ail in Yersinia pseudotuberculosis (161), factor $\mathrm{H}$ binding protein (fHbp) and neisserial surface protein $\mathrm{A}$ (NspA) in N. meningitidis (162), and M protein family in group A streptococci (163).

Factor $\mathrm{H}$ binds to pathogens by a "common microbial binding site," located in its C-terminal domain CCP20. This domain binds to heparin and other GAGs on the host cell surface, but the binding sites for GAG and for pathogens surface proteins are not identical $(164,165)$. Three key amino acids (R1182, R1203, R1206) are critical for this "common microbial binding site" for at least seven Gram-negative and Gram-positive pathogens (165). In addition, the microbial proteins enhanced binding of FH19-20 to $\mathrm{C} 3 \mathrm{~b}$, forming a triple complex, and leading to a more efficient complement inactivation on the pathogen surface. This is a unique example of convergent evolution, resulting in enhanced immune evasion of important pathogens via utilization of a "superevasion site" (165).
RCA-like expression allows pathogens to block complement activation without the need to recruit complement regulator. Synthesis of proteases specifically against complement proteins degrades complement components. The last group is pathogens able to express C3 convertase inhibitors.

In addition to CCP 19-20, pathogens trap $\mathrm{FH}$ by binding to CCP6-8. Neisseria species bind this region of FH. Por1A from Neisseria gonorrhoeae, interacts with CCP 6, in addition to CCP 19-20, to escape from complement attack (166). Also, fHbp and NspA from $N$. meningitidis can recruit $\mathrm{FH}$ by binding to CCP 6-7 $(162,167)$. Study of the structure of fHbp by mutagenesis revealed that fHbp binding site for $\mathrm{CCP} 6-7$ overlaps with sucrose octasulfate, a GAG analog. FhbB from Treponema denticola binds FH by a similar mechanism. Study of FH/FhbB interaction by sitedirected mutagenesis revealed a binding site localized in CCP7 of FH (168).

Staphylococcus aureus has developed a different strategy to prevent complement initiation. Staphylococcal protein A (SpA) recognizes the $\mathrm{Fc}$ portion of Igs with high affinity and hide the binding site for C1q, thus blocking the initiation of the CP (169). The outer membrane protein SdrE binds FH and C4BP to $S$. aureus $(170,171)$. Together, these findings suggest that $S$. aureus is able to inhibit the three complement pathways.

\section{Expression of Complement Regulators-Like Proteins}

Expression of complement regulators-like proteins can contribute to pathogens camouflage. Some viruses, such as poxvirus, have found ways to produce soluble proteins that closely mimic the 
structure and function of host regulators, such as vaccinia virus, which produce VCP, a protein similar to CD55 and MCP. Thus, these viruses inhibit both $\mathrm{CP}$ and $\mathrm{AP}$, dissociating $\mathrm{C} 3$ convertases formed on $\mathrm{C} 3 \mathrm{~b}$ and $\mathrm{C} 4 \mathrm{~b}$. Monkeypox virus produces a complement regulator-like protein, MOPICE, which is able to bind human $\mathrm{C} 3 \mathrm{~b}$ and $\mathrm{C} 4 \mathrm{~b}$ and serves as cofactor for FI (172). MOPICE is considered as a virulence factor of this virus, since it is expressed in the more virulent strains from Central Africa and absent in the less virulent pathogens from West Africa. Another example of complement regulators-like activity comes from Herpes viruses, which express transmembrane gC1 and gC2 glycoproteins able to bind $\mathrm{C} 3 \mathrm{~b}$ and to specifically accelerate the decay of the AP C3 convertase (173). Borrelia burgdorferi produces a CD59-like protein, which has affinity for $\mathrm{C} 8 \mathrm{~b}$ and $\mathrm{C} 9$ and avoids MAC formation (157).

\section{Production of Proteases that Degrade Complement}

Production of proteases that degrade complement proteins is frequently observed in bacteria. Indeed, Pseudomonas produce Pseudomonas elastase $(\mathrm{PaE})$ and alkaline protease $(\mathrm{PaAP})$ that cleaves immunoglobulins and $\mathrm{Clq}$, thus preventing activation of the CP (174). In addition, these proteases are able to inactivate $\mathrm{C} 3$ into a non-functional fragment and inhibit complement activation (174). Leptospira strains are able to cleave directly complement proteins and inhibit the three complement pathways. Leptospira produced metalloproteases may not only cleave C3 but also FB, C4, and C2 (175). Generated C3 degradation products differ from those obtained by FI, suggesting that they would not result in opsonization and phagocytosis. S. aureus is also able to produce distinct proteolytic enzymes against complement proteins. Staphylokinase can form a complex with plasminogen, resulting in a serine protease activity efficient against C3 and IgG. Moreover, plasmin is able to bind the surface of $S$. aureus and inhibits the binding of IgG, C3b, and $\mathrm{iC} 3 \mathrm{~b}$ and blocks the effect of opsonization (176). This enzyme activity leads to the $\mathrm{CP}$ inhibition. $S$. aureus produces four important proteases: cysteine proteases staphopain A and B, serine protease V8, and metalloproteinase Aur. These proteases lead to a drastic decrease in the hemolytic activity of serum and are efficient against the three pathways (177). Aur is responsible for the consumption of $\mathrm{C} 3$ in the fluid phase (178). N. meningitidis is able to produce a protease NalP, which cleaves C3. This degradation produces two fragments, a shorter C3a-like and a longer C3b-like, degraded by host serum and leading to a decreased C3b deposition on the bacterial surface (179). N. meningitidis is able to inhibit the $\mathrm{CP}$ by capsular oligosaccharides, which represents a virulence factor of meningococcal infections (180). Capsular oligosaccharides interfere with engagement of $\mathrm{Clq}$ by IgG Fc, and lead to decreased C4b deposition and inhibition of $\mathrm{CP}$ activation.

Viruses can also produce C3b cleaving enzymes. Nipah virus particles carry a FI-like protease activity able to cleave and inactivate C3b, using FH and CR1, but not CD46, as cofactors (181). These data help to explain how an enveloped virus such as Nipah virus can infect and disseminate through body fluids that are rich in complement.

\section{Production of Inhibitors of C3 Convertase}

Production of inhibitors of C3 convertase has been observed in a few cases. S. aureus produces extracellular fibrinogen-binding protein (Efb), which inhibits the conversion of $\mathrm{C} 3$ to $\mathrm{C} 3 \mathrm{~b}$ by its affinity for the thioesther domain (TED). It binds to the TED domain on an area, shared by FH and CR2 binding sites (182185). Efb acts as a C3 convertase inhibitor by blocking C3b formation and inhibits the opsonophagocytosis by granulocytes (186). Ehp (also known as Ecb), a homologous protein of Efb, binds two molecules of $\mathrm{C} 3 \mathrm{~b}$ and works as an efficient inhibitor of the alternative C3 convertase (187). Thus, it leads to a decrease of the activation of the $\mathrm{C} 5$ convertase and of the resulting C5a level. Surface immunoglobulin-binding protein (Sbi) forms a tripartite complex with $\mathrm{C} 3 \mathrm{~b}$ and functional $\mathrm{FH}$ that potentiates inhibition of complement activation (188). Efb and Sbi are able to recruit human plasminogen after binding to $\mathrm{C} 3 / \mathrm{C} 3 \mathrm{~b}$. Plasminogen is converted to plasmin by bacterial staphylokinase or by host-specific urokinase-type plasminogen activator and degrades $\mathrm{C} 3$ and $\mathrm{C} 3 \mathrm{~b}$ in the local microenvironment, thus protecting S. aureus (184, 189). Of note, the tripartite complex formed by $\mathrm{C} 3$, plasminogen, and Efb-C is more efficient than the one with Sbi, probably due to the higher affinity of C3d to Efb than Sbi, (184). The action of these molecules prevents the activity of the C3 and C5, as shown by a decreased C5a generation (190).

Contrary to Efb, staphylococcal complement inhibitor family (SCIN-A, SCIN-B, SCIN-C), can bind C3b in two distinct regions with a primary site at domain MG8 (191-194). By competing with $\mathrm{FB}$ and FH, SCIN is able to block the formation of alternative $\mathrm{C} 3$ convertase on one side, and to block the generation of $\mathrm{iC} 3 \mathrm{~b}$ that could induce phagocytosis on the other side. Moreover, SCIN binds and stabilizes the $\mathrm{C} 3$ convertase $\mathrm{C} 3 \mathrm{bBb}$, blocks the decay acceleration, and inhibits the cleavage of $\mathrm{C} 3$ into $\mathrm{C} 3 \mathrm{~b}$. Thus, it avoids opsonization and complement activation in the same time (193).

Targeting binding sites for complement inhibitors on bacterial surfaces and complement-degrading proteases with vaccineinduced antibodies may be used as a strategy for novel vaccines designed to prevent complement escape. On the other hand, some bacterial proteins with anti-complement activity, such as Efb and SCIN, represent potential novel therapeutics, able to control undesired complement activation and tissue injury in multiple non-infectious diseases $(195,196)$. It is important to consider that by blocking C3 convertase formation, these inhibitors will avoid opsonophagocytosis and, by such, increase the risk of infection in treated patients (197). The increasing knowledge of the complement evasion strategies of pathogens provides novel insights for more efficient vaccine development and for designing novel therapeutic complement inhibitors.

\section{Complement and Non-Infectious Diseases}

The importance of the complement system in physiology is illustrated by severe and life threatening diseases, occurring in case of inefficient or exuberant complement activity (Figure 10). Abnormal complement activity is associated with a large number of inflammatory, autoimmune, thrombotic, and age-related diseases. The examples of systemic lupus erythematosus (SLE), atypical 


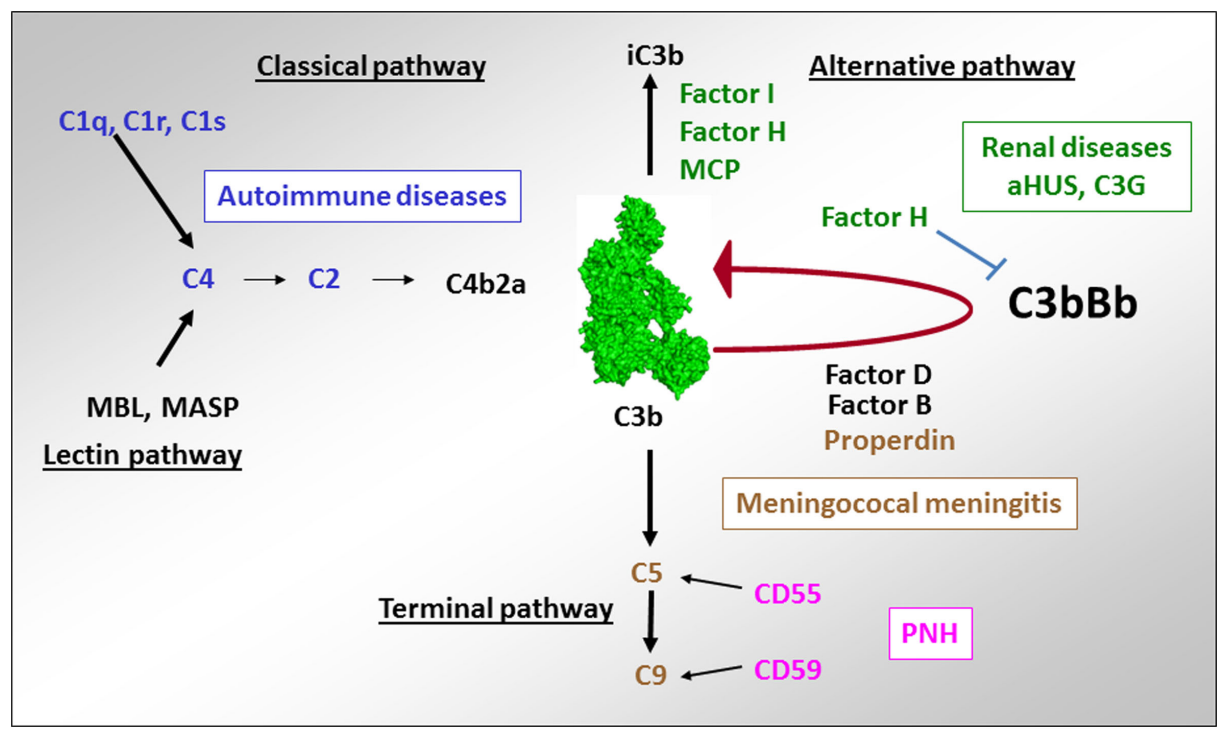

FIGURE 10 | Implication of complement deficiencies in pathologies. Deficiencies of the components of the CP C1q, C1r, C1s, C2, and C4 are associated with autoimmunity. Lack of regulators of the AP FH, CD46, and FI (as well as overactivation of the components of the C3 convertase C3 and FB) is linked to aHUS and C3G. Deficiencies of the terminal complement components
C5, C6, C7, C8, and C9 as well as of the only positive regulator of complement - properdin is susceptibility factors to development of meningococcal meningitis. Lack of expression of the regulators of the C3/C5 convertase CD55 and the terminal pathway CD59 on erythrocytes are a cause of red cell lysis in paroxysmal nocturnal hemoglobinuria (PNH). hemolytic uremic syndrome (aHUS), C3 glomerulopathies (C3G), age-related macular degeneration (AMD), and cancer are treated here in more details, but these are just few among a large list of diseases, including also the paroxysmal nocturnal hemoglobinuria (PNH), graft rejection after transplantation, ischemia/reperfusion injury, Alzheimer and Parkinson diseases, etc.

\section{Diseases Associated with Deficient Complement Activation}

\section{Systemic Lupus Erythematosus}

Deficiency of components of the classical complement pathway $\mathrm{C1q}, \mathrm{C} 1 \mathrm{r}, \mathrm{C} 1 \mathrm{~s}$, and $\mathrm{C} 4$ are very rare but are strongly associated with autoimmune manifestations. The autoimmune disease SLE is characterized by symptoms ranging from skin rashes, chronic fatigue, and arthritis to the more severe glomerulonephritis, serositis, and neurological involvement (198). C1q is the strongest genetic susceptibility factor for SLE, since over $90 \%$ of the individuals homozygous for mutations in this protein develop lupus-like symptoms (199). The mutations can cause quantitative deficiency (199) or functional abnormalities (13). A functional abnormality of $\mathrm{C} 1 \mathrm{q}$, due to a mutation in the $\mathrm{C} 1 \mathrm{r} 2 \mathrm{C} 1 \mathrm{~s} 2$ binding site, resulted in an inability of $\mathrm{C} 1$ complex formation and presence of free $\mathrm{C} 1 \mathrm{q}$ in the patient serum. The strong association of the mutations of the $\mathrm{CP}$ proteins with autoimmunity can be explained by the "waste disposal" hypothesis of Walport (17), suggesting that lack of C1q opsonization and CP activity perturbs the immunologically silent uptake of apoptotic cells and debris, thus resulting in an immune response against self-antigens.

Alteration of the function of $\mathrm{Clq}$ can be also induced by presence of autoantibodies against $\mathrm{Clq}$, which are frequently found in SLE, especially in patients with lupus nephritis (200). These antibodies bind to the collagenous tail of C1q (201) or the globular domain (202). These antibodies amplify the effect of C1q-containing immune complexes in the kidneys $(203,204)$, bind to C1q on early-apoptotic cells, and enhance complement activation (205).

Impaired clearance of apoptotic cells, induced by lack of $\mathrm{Clq}$ or inefficient complement activation due to lack of C1r, C1s, C2, and $\mathrm{C} 4$ are associated with SLE. At the same time, complement overactivation, due to the presence of anti-C1q antibodies or complement activating immune complexes in the circulation and in kidney glomeruli, is also leading to the same disease, albeit by a different mechanism. Therefore, both lack of activation and a too strong activation of the $\mathrm{CP}$ can be linked to autoimmunity.

\section{Diseases Associated with Complement Overactivation}

Inherited and acquired quantitative and functional deficiency of the regulators of the alternative complement pathway FH, FI, and CD46 as well as abnormalities inducing overactivation of the AP C3 convertase are associated with rare renal diseases like aHUS $(206,207)$ and C3G $(208,209)$.

\section{Atypical Hemolytic Uremic Syndrome}

Atypical hemolytic uremic syndrome is a renal thrombotic microangiopathy disease, characterized by glomerular microvascular endothelial cells activation and damage, leading to microthrombi formation and mechanical hemolysis (206). Within the last decade, complement AP dysregulation has emerged as the cause of aHUS $(207,210)$. In this disease, complement induces glomerular endothelium damage, secondary to unrestricted complement activation with C5b-9 deposits on the endothelial 
cells surface. A loss of regulation is a result of mutations in $\mathrm{FH}$, FI, or CD46 genes, found in $\sim 50 \%$ of the cases. $\mathrm{FH}$ mutations are frequently located in the C-terminal domains and result in reduced capacity of $\mathrm{FH}$ to bind $\mathrm{C} 3 \mathrm{~b}$ and the GAG of the cell membrane (211-213). Mutations in FI impair its catalytic activity $(214,215)$. Complement overactivation in $10 \%$ of the cases is due to mutations in the components of the $\mathrm{C} 3$ convertase $\mathrm{C} 3$ and $\mathrm{FB}$, forming a more potent convertase and/or a converatase resistant to decay by the regulators (216-221). In addition to mutations in complement genes, autoantibodies against $\mathrm{FH}$, leading to an acquired FH functional deficiency, have been reported in aHUS patients (222-224). The binding epitopes of these autoantibodies are localized to the $\mathrm{C}$-terminal recognition region of $\mathrm{FH}$, which represents a hot spot for aHUS mutations (225).

Altogether complement-associated abnormalities are found in about $60 \%$ of the aHUS patients $(226,227)$. At present, over 200 distinct mutations have been reported in aHUS patients (207). All reported mutations were heterozygous, except in 15 patients (mostly from consanguineous families) with homozygous $\mathrm{FH}$ or CD46 deficiency (228). In a particular form of aHUS, mutations were found in DGKE - a gene outside of complement, involved in the protein kinase $\mathrm{C}$ signaling pathway (229). Its deficiency induces permanent pro-coagulant phenotype of the endothelial cells (230). aHUS has an incomplete penetrance among the mutation carriers and a triggering event (infection, pregnancy, etc.) and additional genetic predisposing factors (particular at risk haplotypes in $\mathrm{FH}$ and CD46) are needed to induce the disease $(220,231,232)$. The hemolysis, which accompanies the disease onset, can serve as a secondary hit for the aHUS development, since released heme activates the alternative complement pathway in the fluid phase and on the endothelial cells surface $(233,234)$. The availability of the first effective anti-complement therapeutic drug, eculizumab, has changed dramatically the outcome of this rare kidney disease.

\section{C3 Glomerulopathies}

C3 glomerulopathies are rare chronic kidney diseases, characterized by predominant C3 deposits in glomeruli, in particular, in the mesangium and along the glomerular basement membrane, frequently associated with mesangial cells proliferation. According to the pattern of $\mathrm{C} 3$ deposits observed by immunofluorescence and electronic microscopy, two subtypes of $\mathrm{C} 3 \mathrm{G}$ are described dense deposit disease (DDD) and C3 glomerulonephritis (C3GN) (208). The pathogenic process in $\mathrm{C} 3 \mathrm{G}$ is presumed to be due to uncontrolled $\mathrm{C} 3$ and/or C5 convertases activation, leading to C3 deposits and intra-glomerular inflammation. Autoantibodies targeting the AP C3 convertase, named C3 nephritic factor, are present in more than $50 \%$ of C3G patients (235-237). Few genetic abnormalities have been identified. These include mutations of complement genes, coding for C3 (1 case) (238) and the regulator $\mathrm{FH}(<20$ mutations) $(237,239)$. Mutations affecting $\mathrm{FH}$ gene result more frequently a protein deficiency in the plasma. More recently, mutations in the CFHR5 gene were reported, as well as rearrangements and copy number variations in the CFHR gene cluster (240-242). A particular form of C3GN is the CFHR5 nephropathy, characterized by a genetic defect in CFHR5, rendering it a strong competitor of FH. It is found in patients from of Cypriot descent $(241,243)$.

In C3G, genetic abnormalities affect the same genes as in aHUS, with a lesser frequency compared to aHUS, affecting only about $20 \%$ of the patients $(209,237)$. An interesting observation is that the mutations in $\mathrm{FH}$ and in FI, which are associated with $\mathrm{C} 3 \mathrm{G}$, are frequently the same, as the ones found in aHUS. They induce either complete or partial FH deficiency or functional defects in the N-terminal part of the protein (237). Mutations in the membrane anchoring C-terminal part of $\mathrm{FH}$ are found frequently in aHUS and nearly not in C3G. Therefore, the mutation itself (particularly the deficiencies of FH and FI and the mutations in the N-terminal part of $\mathrm{FH}$ ) may not be sufficient to determine the type of the renal injury. The triggers of the AP dysregulation remain undetermined.

C3 nephritic factor and FH or FI mutations, inducing an overactivation of the AP are found also in patients with another type of membranoproliferative glomerulonephritis, associated with immunoglobulin deposits in the kidney - MPGN type I (237). Therefore, the role of the AP has to be considered even in diseases, for which CP activation is expected.

\section{Contribution of Complement in Diseases, not Associated with Complement Defects Age-Related Macular Degeneration}

A particular polymorphism of $\mathrm{FH}(\mathrm{Y} 402 \mathrm{H})$ is strongly associated with development of AMD, which is the first cause of blindness in the developed countries (244-247). The loss of central vision is associated with loss of photoreceptors and drusen formation in the retina (248). This is due to the constant exposure to light, smoking, the high-metabolic rate in the eye, and its particular sensibility to oxidative stress. Oxidized lipids and malondialdehyde are generated and if not properly handled by $\mathrm{FH}$, they induce complement activation $(249,250)$ (Figure 11). FH binding to oxidized epitopes on altered or dying cells leads to inactivation of $\mathrm{C} 3 \mathrm{~b}$ to an anti-inflammatory fragment $\mathrm{iC} 3 \mathrm{~b}$. Moreover, $\mathrm{FH}$ attenuates malondialdehyde-induced IL- 8 production by macrophages and retinal pigment epithelial cells and decreases the expression of genes involved in macrophage infiltration, inflammation, and neovascularization in the eye. At risk, $\mathrm{FH}$ variant $\mathrm{H} 402$ has a weaker capacity to interact with oxidized lipids and malondialdehyde in the drusen, thus allowing constant background complement activation, leading to retinal epithelial cells damage and macrophages activation $(249,250)$. These results explain the strong genetic association of the $\mathrm{H} 402$ with the risk of AMD. Increased risk for $\mathrm{AMD}$ is conferred also by polymorphisms in several other genes of the alternative complement pathway, including FI, C3, C2/FB, and C9 (251).

Genetic analyses revealed that the deletion of CFHR1 and CFHR3, which is a polymorphism in the normal population with varying frequency depending on the ethnicity between 2 and $20 \%$ (252), is a protective factor against development of AMD (253). CFHR1 and CFHR3 are natural deregulators of FH, competing with it for cell surface binding $(241,254,255)$. Therefore, their absence will increase the local binding of $\mathrm{FH}$ to oxidized surfaces, leading to a better protection, thus explaining the protective effect of this deletion in AMD. 


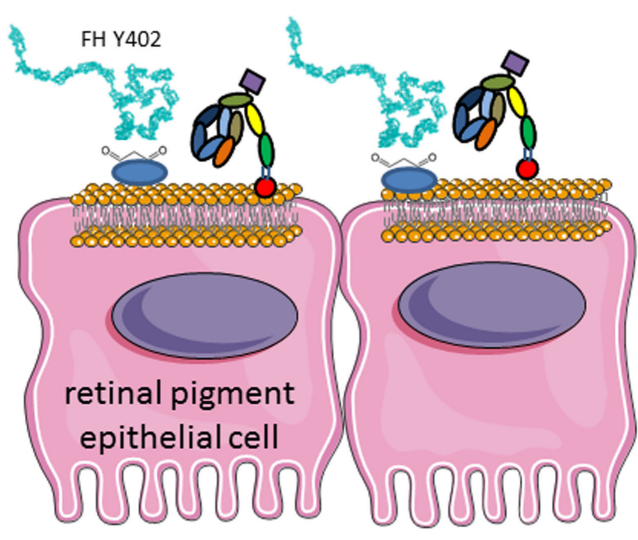

Anti-inflammatory effect

Healthy

FIGURE 11 | Role of factor H Y402H polymorphism in age-related macular degeneration. FH binds to GAG, oxidized lipids, including malondialdehyde via CCP7 on the membrane of injured retinal epithelial (RPE) cells and protects them from complement attack. $\mathrm{H} 402$ variant has a weaker affinity to these products of the oxidative stress and protects less well the cells

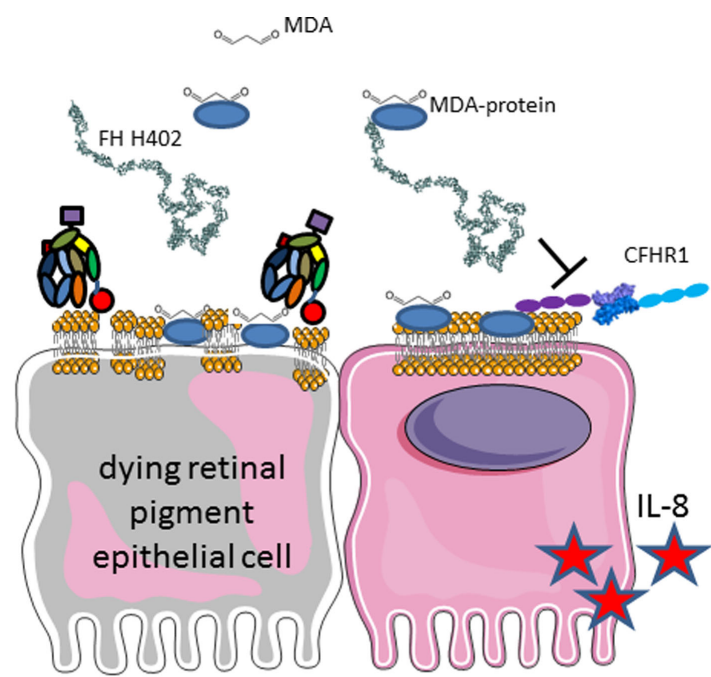

Pro-inflammatory effect

AMD

\section{Cancer}

Complement has been considered since a long time as an immune surveillance system against cancer, because complement is activated on the surface of tumor cells. Nevertheless, tumor cells develop inhibitory mechanisms for the terminal steps of the complement cascade, thus preventing complementmediated cytotoxicity. Surprisingly, recent studies demonstrated that complement activation within the tumor microenvironment can promote tumor growth. Complement activation may support chronic inflammation, promote an immunosuppressive microenvironment, induce angiogenesis, and activate cancerrelated signaling pathways. The mechanisms of these phenomena are not fully understood. Prolonged complement activation supports chronic inflammation, promotes an immunosuppressive microenvironment, induces angiogenesis, and activates cancerrelated signaling pathways.

Several lines of evidence indicate a role for molecules of the complement system in tumor growth and metastasis, (Figure 12). $\mathrm{C} 3, \mathrm{C} 4$, or $\mathrm{C} 5 \mathrm{aR}$ deficiencies prevent tumor growth in mice, potentially via inhibition of the $\mathrm{CP}$ and the generation of $\mathrm{C} 5 \mathrm{a}$, which has a potent inflammatory potential. In mouse models, the presence of $\mathrm{C} 5 \mathrm{a}$ in the tumor microenvironment enhances tumor growth by recruitment of MDSC and increasing T cell-directed suppressive abilities $(103,256,257)$. In a breast cancer model, $\mathrm{C} 5 \mathrm{aR}$ facilitated metastasis in the lungs through different immune mechanisms in the metastatic niche, including the suppression of effector CD8(+) and CD4(+) T cell responses, the recruitment of immature myeloid cells and the generation of Tregs and a Th2-oriented response (258).
Cancer cells also secrete complement proteins that stimulate tumor growth upon activation via a direct autocrine effect through $\mathrm{C} 3 \mathrm{aR}$ and $\mathrm{C} 5 \mathrm{aR}$ signaling (256). In patients with ovarian or lung cancer, higher tumoral C3 or C5aR mRNA levels were associated with decreased overall survival. In addition, patients with nonsmall cell lung cancer have elevated C5a plasma levels (257).

$\mathrm{C} 3 \mathrm{a}$ and $\mathrm{C} 5 \mathrm{a}$ seem to have opposing effects during tumor development and in case of anti-tumor radiotherapy. While $\mathrm{C} 3 \mathrm{a}$ and especially C5a promote tumor growth, radiotherapy-induced tumor cell death and transient local complement activation with production of C3a and C5a (259). The latter appeared crucial to the tumor response to radiotherapy and concomitant stimulation of tumor-specific immunity.

Overexpression of $\mathrm{FH}$ has been described in non-small cell lung cancer cell lines and on non-small cell lung cancer biopsies (but not in small cell lung carcinoma and carcinoid cell lines) $(260,261)$, in bladder tumor cells $(262)$, in cutaneous squamous cell carcinoma (cSCC) and cell lines (263), and in hepatocellular carcinoma tumors (264). Low titer anti-FH antibodies were also found in sera from patients with non-small cell lung cancer (265). Recent studies demonstrated that FH binds to pentraxin 3 (PTX3) in the tumor microenvironment, thus preventing local complement overactivation and generation of pro-tumorigenic C5a (266). Hence, deficiency of PTX3 accelerated tumor development in mouse models of drug-induced cancerogenesis. FI was also suggested to be associated with tumor development of cSCC (267). These results provided evidence for a potential role of $\mathrm{FH}$ and FI in the cancer development, but the mechanism of action are still unknown. 


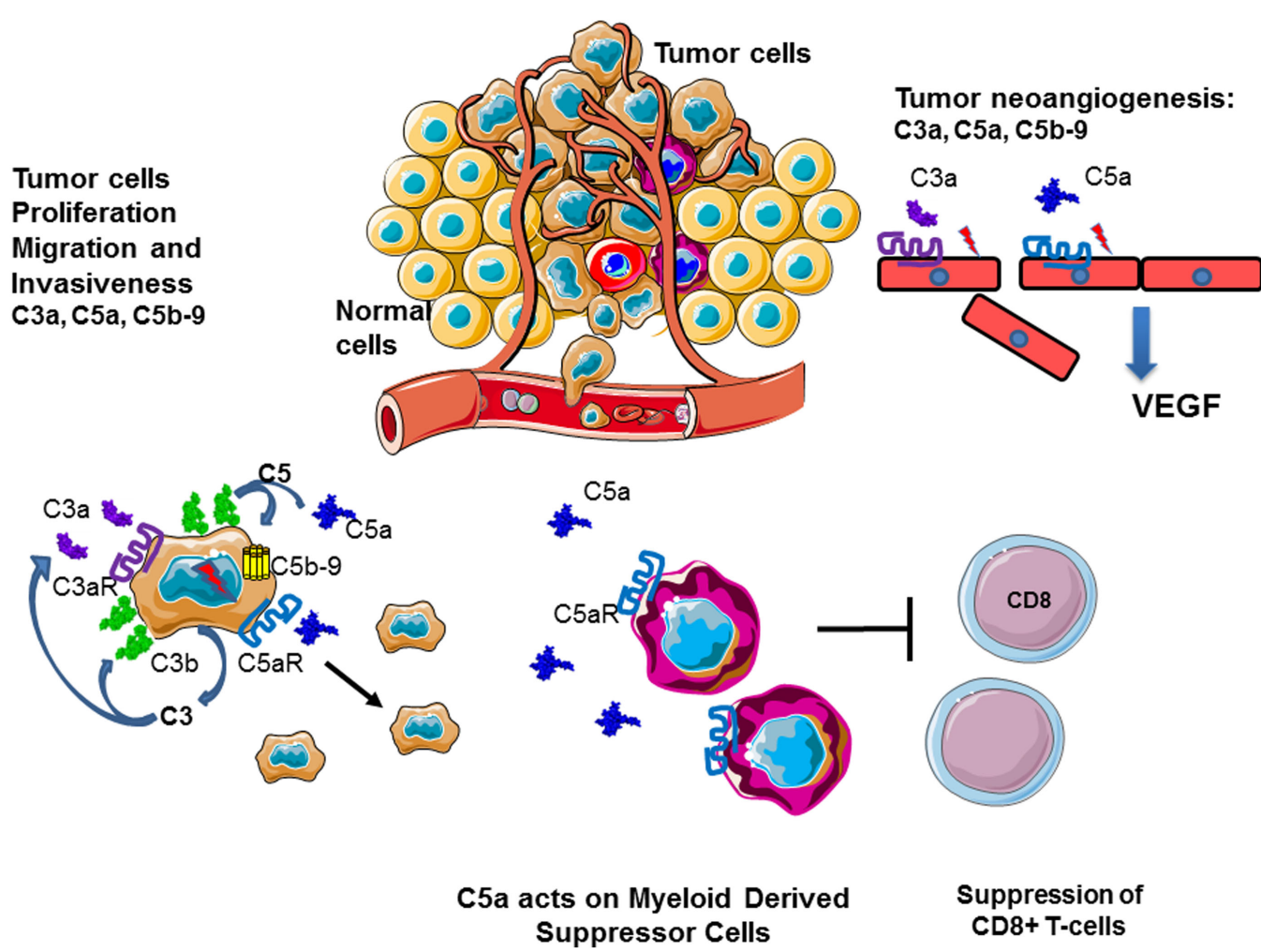

FIGURE 12 | Role of complement in cancer. Complement plays an important role in the chronic inflammation and tumor development. Tumor cells produce complement components and generate $\mathrm{C} 3 \mathrm{a}, \mathrm{C} 5 \mathrm{a}$, and C5b-9 in their microenvironment. This result in autocrine tumor cells stimulation, leading to proliferation, migration, and invasiveness. C5a stimulates MDSC, which dampen the immune response, suppressing cytotoxic T cells, and stimulate Treg. C3a, $\mathrm{C} 5 \mathrm{a}$, and $\mathrm{C} 5 \mathrm{~b}-9$ promote angiogenesis, helping in tumor nutrient support and dissemination.
These examples clearly indicate that complement is indispensable immunosurveillance system, which needs to function with the right force when and where is needed. Therefore, therapeutic strategies are needed to adjust the level of complement activation in pathological conditions.

\section{Complement as a Therapeutic Target}

Since $\mathrm{Clq}$ is produced by the myeloid cells, a bone marrow transplantation can overcome this deficiency. Such therapy was efficiently applied to a patient with SLE, resulting in normalization of C1q levels and improvement of the clinical status (268). Deficiency of C1INH in hereditary and autoimmune angioedema (which is not a complement-mediated disease, but induced by excessive production of bradykinin, which is a potent vasodilator) is efficiently treated by plasma derived or recombinant $\mathrm{C} 1 \mathrm{INH}$ (269). Alternatively, missing soluble complement components can be introduced to the body by plasma exchange. This was successfully achieved for C1q (270) as well as for FH and FI deficiency in aHUS. Plasma therapy was the first line treatment for aHUS before the development of anti-C5 blocking antibody eculizumab $(271,272)$. Eculizumab binds to $C 5$ and prevents its entry into the C5 convertase, thus blocking completely the generation of C5a and the formation of MAC (273). This therapeutic is approved for use in PNH and aHUS and gives excellent results $(274,275)$. Currently, clinical trials are ongoing for many different diseases, where complement is overactivated. Novel inhibitors are under development to block complement at different levels. Particular interest is focused on the blockers of complement at the level of C3 and the C3 convertase. C3b binding peptide compstatin and its derivatives prevent the entry of C3 into the C3 convertase (276, 277). Plasma derived or recombinant $\mathrm{FH}$ and recombinant soluble $\mathrm{CR} 1$ dissociate the alternative $\mathrm{C} 3$ convertase and serve as cofactors for FI (278). Targeted inhibitors like TT30 (FH CCP1-5:CR2) or mini FH (CCP1-4:CCP19-20) bring the regulatory N-terminal domains to the cell membrane, where they are needed to control complement activation (279-282).

\section{Conclusion}

Complement plays a central role in the homeostasis and the installation of the adaptive innate immune response. By its supporting role in the clearance of apoptotic and necrotic cells, and its importance in the polarization of T lymphocytes and the humoral response by the cooperation with the B-lymphocytes, complement represents a real keystone of the immune system. This crucial role for the correct functioning of the organism is illustrated by the fact that both complement deficiencies and complement overactivation are associated with severe and life threatening diseases. The improvement of our understanding of the role of complement in health and disease opens up the possibility to use complement modulating drugs in the clinical practice. 


\section{Acknowledgments}

This work was supported by grants from: SIRIC-CARPEM and ARC no. PJA 20141201954 to LR and ANR Genopath 2009-2012

\section{References}

1. Merle NS, Church SE, Fremeaux-Bacchi V, Roumenina LT. Complement system part I - molecular mechanisms of activation and regulation. Front Immunol (2015) 6:262. doi:10.3389/fimmu.2015.00262

2. Lachmann PJ, Halbwachs L. The influence of C3b inactivator (KAF) concentration on the ability of serum to support complement activation. Clin Exp Immunol (1975) 21:109-14.

3. Kroemer G, Galluzzi L, Vandenabeele P, Abrams J, Alnemri ES, Baehrecke $\mathrm{EH}$, et al. Classification of cell death: recommendations of the nomenclature committee on cell death 2009. Cell Death Differ (2009) 16:3-11. doi:10.1038/ cdd.2008.150

4. Galvan MD, Greenlee-Wacker MC, Bohlson SS. C1q and phagocytosis: the perfect complement to a good meal. J Leukoc Biol (2012) 92:489-97. doi:10. 1189/jlb.0212099

5. Ricklin D, Hajishengallis G, Yang K, Lambris JD. Complement: a key system for immune surveillance and homeostasis. Nat Immunol (2010) 11:785-97. doi:10.1038/ni.1923

6. Païdassi H, Tacnet-Delorme P, Garlatti V, Darnault C, Ghebrehiwet B, Gaboriaud $\mathrm{C}$, et al. $\mathrm{Clq}$ binds phosphatidylserine and likely acts as a multiligand-bridging molecule in apoptotic cell recognition. J Immunol (2008) 1950(180):2329-38. doi:10.4049/jimmunol.180.4.2329

7. Païdassi H, Tacnet-Delorme P, Verneret M, Gaboriaud C, Houen G, Duus $\mathrm{K}$, et al. Investigations on the C1q-calreticulin-phosphatidylserine interactions yield new insights into apoptotic cell recognition. J Mol Biol (2011) 408:277-90. doi:10.1016/j.jmb.2011.02.029

8. Terrasse R, Tacnet-Delorme P, Moriscot C, Pérard J, Schoehn G, Vernet $\mathrm{T}$, et al. Human and pneumococcal cell surface glyceraldehyde-3phosphate dehydrogenase (GAPDH) proteins are both ligands of human C1q protein. J Biol Chem (2012) 287:42620-33. doi:10.1074/jbc. M112.423731

9. Verneret M, Tacnet-Delorme P, Osman R, Awad R, Grichine A, Kleman J-P, et al. Relative contribution of $\mathrm{clq}$ and apoptotic cell-surface calreticulin to macrophage phagocytosis. J Innate Immun (2014) 6:426-34. doi:10.1159/ 000358834

10. Fraser DA, Laust AK, Nelson EL, Tenner AJ. C1q differentially modulates phagocytosis and cytokine responses during ingestion of apoptotic cells by human monocytes, macrophages, and dendritic cells. J Immunol (2009) 1950(183):6175-85. doi:10.4049/jimmunol.0902232

11. Castellano G, Woltman AM, Schlagwein N, Xu W, Schena FP, Daha MR, et al. Immune modulation of human dendritic cells by complement. Eur J Immunol (2007) 37:2803-11. doi:10.1002/eji.200636845

12. Pickering MC, Botto M, Taylor PR, Lachmann PJ, Walport MJ. Systemic lupus erythematosus, complement deficiency, and apoptosis. Adv Immunol (2000) 76:227-324. doi:10.1016/S0065-2776(01)76021-X

13. Roumenina LT, Sène D, Radanova M, Blouin J, Halbwachs-Mecarelli L, Dragon-Durey M-A, et al. Functional complement $\mathrm{Clq}$ abnormality leads to impaired immune complexes and apoptotic cell clearance. J Immunol (2011) 1950(187):4369-73. doi:10.4049/jimmunol.1101749

14. Ogden CA, deCathelineau A, Hoffmann PR, Bratton D, Ghebrehiwet B, Fadok VA, et al. C1q and mannose binding lectin engagement of cell surface calreticulin and CD91 initiates macropinocytosis and uptake of apoptotic cells. J Exp Med (2001) 194:781-95. doi:10.1084/jem.194.6.781

15. Benoit ME, Clarke EV, Morgado P, Fraser DA, Tenner AJ. Complement protein $\mathrm{C} 1 \mathrm{q}$ directs macrophage polarization and limits inflammasome activity during the uptake of apoptotic cells. J Immunol (2012) 1950(188):5682-93. doi:10.4049/jimmunol.1103760

16. Clarke EV, Weist BM, Walsh CM, Tenner AJ. Complement protein C1q bound to apoptotic cells suppresses human macrophage and dendritic cell-mediated Th17 and Th1 T cell subset proliferation. J Leukoc Biol (2015) 97:147-60. doi:10.1189/jlb.3A0614-278R

17. Walport MJ. Complement. Second of two parts. N Engl J Med (2001) 344:1140-4. doi:10.1056/NEJM200104123441506
09geno03101I, APHP-PHRC AOM08198 and EU FP7 grant 2012 305608 (EURenOmics) to VF-B and by INSERM. The shapes of the cells used in this review are inspired by http://smart.servier.fr/ servier-medical-art.

18. Baruah P, Dumitriu IE, Malik TH, Cook HT, Dyson J, Scott D, et al. C1q enhances IFN-gamma production by antigen-specific $\mathrm{T}$ cells via the CD40 costimulatory pathway on dendritic cells. Blood (2009) 113:3485-93. doi:10. 1182/blood-2008-06-164392

19. Garg AD, Krysko DV, Verfaillie T, Kaczmarek A, Ferreira GB, Marysael T, et al. A novel pathway combining calreticulin exposure and ATP secretion in immunogenic cancer cell death. EMBO J (2012) 31:1062-79. doi:10.1038/ emboj.2011.497

20. Said G, Guilbert M, Morjani H, Garnotel R, Jeannesson P, El Btaouri H. Extracellular matrix proteins modulate antimigratory and apoptotic effects of doxorubicin. Chemother Res Pract (2012) 2012:268681. doi:10.1155/2012/ 268681

21. Amarilyo G, Verbovetski I, Atallah M, Grau A, Wiser G, Gil O, et al. iC3b-opsonized apoptotic cells mediate a distinct anti-inflammatory response and transcriptional NF-kappaB-dependent blockade. Eur J Immunol (2010) 40:699-709. doi:10.1002/eji.200838951

22. Mevorach D, Mascarenhas JO, Gershov D, Elkon KB. Complement-dependent clearance of apoptotic cells by human macrophages. J Exp Med (1998) 188:2313-20. doi:10.1084/jem.188.12.2313

23. Morelli AE, Larregina AT, Shufesky WJ, Zahorchak AF, Logar AJ, Papworth $\mathrm{GD}$, et al. Internalization of circulating apoptotic cells by splenic marginal zone dendritic cells: dependence on complement receptors and effect on cytokine production. Blood (2003) 101:611-20. doi:10.1182/blood-2002-06-1769

24. Verbovetski I, Bychkov H, Trahtemberg U, Shapira I, Hareuveni M, Ben-Tal O, et al. Opsonization of apoptotic cells by autologous iC3b facilitates clearance by immature dendritic cells, down-regulates DR and CD86, and up-regulates CC chemokine receptor 7. J Exp Med (2002) 196:1553-61. doi:10.1084/jem. 20020263

25. Liszewski MK, Kolev M, Le Friec G, Leung M, Bertram PG, Fara AF, et al. Intracellular complement activation sustains $\mathrm{T}$ cell homeostasis and mediates effector differentiation. Immunity (2013) 39:1143-57. doi:10.1016/j.immuni. 2013.10.018

26. André C, Cota D. Coupling nutrient sensing to metabolic homoeostasis: the role of the mammalian target of rapamycin complex 1 pathway. Proc Nutr Soc (2012) 71:502-10. doi:10.1017/S0029665112000754

27. Strainic MG, Liu J, Huang D, An F, Lalli PN, Muqim N, et al. Locally produced complement fragments $\mathrm{C} 5 \mathrm{a}$ and $\mathrm{C} 3 \mathrm{a}$ provide both costimulatory and survival signals to naive CD4+ T cells. Immunity (2008) $\mathbf{2 8 : 4 2 5 - 3 5}$. doi:10.1016/j. immuni.2008.02.001

28. Peng Q, Li K, Patel H, Sacks SH, Zhou W. Dendritic cell synthesis of C3 is required for full $\mathrm{T}$ cell activation and development of a Th1 phenotype. J Immunol (2006) 1950(176):3330-41. doi:10.4049/jimmunol.176.6.3330

29. Laplante M, Sabatini DM. mTOR signaling at a glance. J Cell Sci (2009) 122:3589-94. doi:10.1242/jcs.051011

30. Kishore U, Ghai R, Greenhough TJ, Shrive AK, Bonifati DM, Gadjeva MG, et al. Structural and functional anatomy of the globular domain of complement protein C1q. Immunol Lett (2004) 95:113-28. doi:10.1016/j.imlet.2004.06.015

31. Roumenina LT, Popov KT, Bureeva SV, Kojouharova M, Gadjeva M, Rabheru $\mathrm{S}$, et al. Interaction of the globular domain of human C1q with Salmonella typhimurium lipopolysaccharide. Biochim Biophys Acta (2008) 1784:1271-6. doi:10.1016/j.bbapap.2008.04.029

32. Albertí S, Marqués G, Hernández-Allés S, Rubires X, Tomás JM, Vivanco F, et al. Interaction between complement subcomponent $\mathrm{C1q}$ and the Klebsiella pneumoniae porin OmpK36. Infect Immun (1996) 64:4719-25.

33. Ezekowitz RA. Role of the mannose-binding lectin in innate immunity. J Infect Dis (2003) 187(Suppl 2):S335-9. doi:10.1086/374746

34. Dimitrov JD, Planchais C, Roumenina LT, Vassilev TL, Kaveri SV, LacroixDesmazes S. Antibody polyreactivity in health and disease: statu variabilis. J Immunol (2013) 1950(191):993-9. doi:10.4049/jimmunol.1300880

35. Gaboriaud C, Thielens NM, Gregory LA, Rossi V, Fontecilla-Camps JC, Arlaud GJ. Structure and activation of the $\mathrm{Cl}$ complex of complement: unraveling the puzzle. Trends Immunol (2004) 25:368-73. doi:10.1016/j.it. 2004.04 .008 
36. Roumenina LT, Kantardjiev AA, Atanasov BP, Waters P, Gadjeva M, Reid $\mathrm{KBM}$, et al. Role of $\mathrm{Ca} 2+$ in the electrostatic stability and the functional activity of the globular domain of human C1q. Biochemistry (2005) 44:14097-109. doi:10.1021/bi051186n

37. Kjaer TR, Thiel S, Andersen GR. Toward a structure-based comprehension of the lectin pathway of complement. Mol Immunol (2013) 56:413-22. doi:10. 1016/j.molimm.2013.05.220

38. Degn SE, Kjaer TR, Kidmose RT, Jensen L, Hansen AG, Tekin M, et al. Complement activation by ligand-driven juxtaposition of discrete pattern recognition complexes. Proc Natl Acad Sci US A (2014) 111:13445-50. doi:10. 1073/pnas.1406849111

39. Kidmose RT, Laursen NS, Dobó J, Kjaer TR, Sirotkina S, Yatime L, et al. Structural basis for activation of the complement system by component C4 cleavage. Proc Natl Acad Sci U S A (2012) 109:15425-30. doi:10.1073/pnas. 1208031109

40. Gál P, Harmat V, Kocsis A, Bián T, Barna L, Ambrus G, et al. A true autoactivating enzyme. Structural insight into mannose-binding lectin-associated serine protease-2 activations. J Biol Chem (2005) 280:33435-44. doi:10.1074/ jbc.M506051200

41. Kinoshita T, Takata Y, Kozono H, Takeda J, Hong KS, Inoue K. C5 convertase of the alternative complement pathway: covalent linkage between two C3b molecules within the trimolecular complex enzyme. J Immunol (1988) 1950(141):3895-901.

42. Bubeck D. The making of a macromolecular machine: assembly of the membrane attack complex. Biochemistry (2014) 53:1908-15. doi:10.1021/bi500157z

43. Joiner K, Brown E, Hammer C, Warren K, Frank M. Studies on the mechanism of bacterial resistance to complement-mediated killing. III. C5b-9 deposits stably on rough and type $7 \mathrm{~S}$. pneumoniae without causing bacterial killing. J Immunol (1983) 130:845-9.

44. Bhakdi S, Kuller G, Muhly M, Fromm S, Seibert G, Parrisius J. Formation of transmural complement pores in serum-sensitive Escherichia coli. Infect Immun (1987) 55:206-10.

45. Lewis LA, Ram S. Meningococcal disease and the complement system. Virulence (2014) 5:98-126. doi:10.4161/viru.26515

46. Cole DS, Morgan BP. Beyond lysis: how complement influences cell fate. Clin Sci (Lond) (2003) 1979(104):455-66. doi:10.1042/CS20020362

47. Morgan BP. Complement membrane attack on nucleated cells: resistance, recovery and non-lethal effects. Biochem J (1989) 264:1-14.

48. Campbell DG, Gagnon J, Reid KB, Williams AF. Rat brain Thy-1 glycoprotein. The amino acid sequence, disulphide bonds and an unusual hydrophobic region. Biochem J (1981) 195:15-30.

49. Morgan BP, Campbell AK. The recovery of human polymorphonuclear leucocytes from sublytic complement attack is mediated by changes in intracellular free calcium. Biochem J (1985) 231:205-8.

50. Bohnsack JF, O'Shea JJ, Takahashi T, Brown EJ. Fibronectin-enhanced phagocytosis of an alternative pathway activator by human culture-derived macrophages is mediated by the $\mathrm{C} 4 \mathrm{~b} / \mathrm{C} 3 \mathrm{~b}$ complement receptor (CR1). J Immunol (1985) 1950(135):2680-6.

51. Griffin FM, Mullinax PJ. High concentrations of bacterial lipopolysaccharide, but not microbial infection-induced inflammation, activate macrophage C3 receptors for phagocytosis. J Immunol (1990) 1950(145):697-701.

52. Tosi MF, Zakem H, Berger M. Neutrophil elastase cleaves C3bi on opsonized Pseudomonas as well as CR1 on neutrophils to create a functionally important opsonin receptor mismatch. J Clin Invest (1990) 86:300-8. doi:10.1172/ JCI114699

53. Dupuy AG, Caron E. Integrin-dependent phagocytosis: spreading from microadhesion to new concepts. J Cell Sci (2008) 121:1773-83. doi:10.1242/ jcs.018036

54. Uotila LM, Aatonen M, Gahmberg CG. Integrin CD11c/CD18 $\alpha$-chain phosphorylation is functionally important. J Biol Chem (2013) 288:33494-9. doi:10. 1074/jbc.C113.497446

55. Ross GD, Vetvicka V. CR3 (CD11b, CD18): a phagocyte and NK cell membrane receptor with multiple ligand specificities and functions. Clin Exp Immunol (1993) 92:181-4. doi:10.1111/j.1365-2249.1993.tb03377.x

56. Aderem A, Underhill DM. Mechanisms of phagocytosis in macrophages. Annu Rev Immunol (1999) 17:593-623. doi:10.1146/annurev.immunol.17.1.593

57. Gorgani NN, He JQ, Katschke KJ, Helmy KY, Xi H, Steffek M, et al. Complement receptor of the Ig superfamily enhances complement-mediated phagocytosis in a subpopulation of tissue resident macrophages. J Immunol (2008) 1950(181):7902-8. doi:10.4049/jimmunol.181.11.7902
58. Mayadas TN, Cullere X. Neutrophil beta2 integrins: moderators of life or death decisions. Trends Immunol (2005) 26:388-95. doi:10.1016/j.it.2005.05.002

59. Klos A, Tenner AJ, Johswich K-O, Ager RR, Reis ES, Köhl J. The role of the anaphylatoxins in health and disease. Mol Immunol (2009) 46:2753-66. doi:10.1016/j.molimm.2009.04.027

60. Klos A, Wende E, Wareham KJ, Monk PN. International union of basic and clinical pharmacology. [corrected]. LXXXVII. Complement peptide C5a, C4a, and C3a receptors. Pharmacol Rev (2013) 65:500-43. doi:10.1124/pr.111. 005223

61. Murakami Y, Imamichi T, Nagasawa S. Characterization of C3a anaphylatoxin receptor on guinea-pig macrophages. Immunology (1993) 79:633-8.

62. Elsner J, Oppermann M, Czech W, Dobos G, Schöpf E, Norgauer J, et al. $\mathrm{C} 3 \mathrm{a}$ activates reactive oxygen radical species production and intracellular calcium transients in human eosinophils. Eur J Immunol (1994) 24:518-22. doi:10.1002/eji.1830240304

63. Elsner J, Oppermann M, Czech W, Kapp A. C3a activates the respiratory burst in human polymorphonuclear neutrophilic leukocytes via pertussis toxinsensitive G-proteins. Blood (1994) 83:3324-31.

64. Kretzschmar T, Jeromin A, Gietz C, Bautsch W, Klos A, Köhl J, et al. Chronic myelogenous leukemia-derived basophilic granulocytes express a functional active receptor for the anaphylatoxin C3a. Eur J Immunol (1993) 23:558-61. doi:10.1002/eji.1830230239

65. el-Lati SG, Dahinden CA, Church MK. Complement peptides C3a- and C5ainduced mediator release from dissociated human skin mast cells. J Invest Dermatol (1994) 102:803-6. doi:10.1111/1523-1747.ep12378589

66. Coulthard LG, Woodruff TM. Is the complement activation product C3a a proinflammatory molecule? Re-evaluating the evidence and the myth. J Immunol (2015) 1950(194):3542-8. doi:10.4049/jimmunol.1403068

67. Chen N-J, Mirtsos C, Suh D, Lu Y-C, Lin W-J, McKerlie C, et al. C5L2 is critical for the biological activities of the anaphylatoxins C5a and C3a. Nature (2007) 446:203-7. doi:10.1038/nature05559

68. Daffern PJ, Pfeifer PH, Ember JA, Hugli TE. C3a is a chemotaxin for human eosinophils but not for neutrophils. I. C3a stimulation of neutrophils is secondary to eosinophil activation. J Exp Med (1995) 181:2119-27. doi:10.1084/ jem.181.6.2119

69. Hollmann TJ, Mueller-Ortiz SL, Braun MC, Wetsel RA. Disruption of the $\mathrm{C} 5 \mathrm{a}$ receptor gene increases resistance to acute Gram-negative bacteremia and endotoxic shock: opposing roles of C3a and C5a. Mol Immunol (2008) 45:1907-15. doi:10.1016/j.molimm.2007.10.037

70. Wu MCL, Brennan FH, Lynch JPL, Mantovani S, Phipps S, Wetsel RA, et al. The receptor for complement component $\mathrm{C} 3$ a mediates protection from intestinal ischemia-reperfusion injuries by inhibiting neutrophil mobilization. Proc Natl Acad Sci U S A (2013) 110:9439-44. doi:10.1073/pnas.1218815110

71. Tsuruta T, Yamamoto T, Matsubara S, Nagasawa S, Tanase S, Tanaka J, et al. Novel function of $\mathrm{C} 4 \mathrm{a}$ anaphylatoxin. Release from monocytes of protein which inhibits monocyte chemotaxis. Am J Pathol (1993) 142:1848-57.

72. Zhao Y, Xu H, Yu W, Xie B-D. Complement anaphylatoxin C4a inhibits C5ainduced neointima formation following arterial injury. Mol Med Rep (2014) 10:45-52. doi:10.3892/mmr.2014.2176

73. Barnum SR. C4a: an anaphylatoxin in name only. J Innate Immun (2015) doi:10.1159/000371423

74. Campbell WD, Lazoura E, Okada N, Okada H. Inactivation of C3a and C5a octapeptides by carboxypeptidase R and carboxypeptidase N. Microbiol Immunol (2002) 46:131-4. doi:10.1111/j.1348-0421.2002.tb02669.x

75. Matthews KW, Mueller-Ortiz SL, Wetsel RA. Carboxypeptidase N: a pleiotropic regulator of inflammation. Mol Immunol (2004) 40:785-93. doi:10. 1016/j.molimm.2003.10.002

76. Mueller-Ortiz SL, Wang D, Morales JE, Li L, Chang J-Y, Wetsel RA. Targeted disruption of the gene encoding the murine small subunit of carboxypeptidase N (CPN1) causes susceptibility to C5a anaphylatoxin-mediated shock J Immunol (2009) 1950(182):6533-9. doi:10.4049/jimmunol.0804207

77. Shao Z, Nishimura T, Leung LLK, Morser J. Carboxypeptidase B2 deficiency reveals opposite effects of complement $\mathrm{C} 3 \mathrm{a}$ and $\mathrm{C} 5 \mathrm{a}$ in a murine polymicrobial sepsis model. J Thromb Haemost (2015). doi:10.1111/jth.12956

78. Sayah S, Jauneau AC, Patte C, Tonon MC, Vaudry H, Fontaine M. Two different transduction pathways are activated by $\mathrm{C} 3 \mathrm{a}$ and $\mathrm{C} 5 \mathrm{a}$ anaphylatoxins on astrocytes. Brain Res Mol Brain Res (2003) 112:53-60. doi:10.1016/S0169-328X(03) 00046-9

79. Schatz-Jakobsen JA, Yatime L, Larsen C, Petersen SV, Klos A, Andersen GR. Structural and functional characterization of human and murine C5a 
anaphylatoxins. Acta Crystallogr D Biol Crystallogr (2014) 70:1704-17. doi:10. $1107 / \mathrm{S} 139900471400844 \mathrm{X}$

80. Crass T, Raffetseder U, Martin U, Grove M, Klos A, Köhl J, et al. Expression cloning of the human C3a anaphylatoxin receptor (C3aR) from differentiated U-937 cells. Eur J Immunol (1996) 26:1944-50. doi:10.1002/eji. 1830260840

81. Wilken HC, Götze O, Werfel T, Zwirner J. C3a(desArg) does not bind to and signal through the human C3a receptor. Immunol Lett (1999) 67:141-5. doi:10.1016/S0165-2478(99)00002-4

82. Venkatesha RT, Berla Thangam E, Zaidi AK, Ali H. Distinct regulation of C3ainduced MCP-1/CCL2 and RANTES/CCL5 production in human mast cells by extracellular signal regulated kinase and PI3 kinase. Mol Immunol (2005) 42:581-7. doi:10.1016/j.molimm.2004.09.009

83. Hartmann K, Henz BM, Krüger-Krasagakes S, Köhl J, Burger R, Guhl S, et al. C3a and C5a stimulate chemotaxis of human mast cells. Blood (1997) 89:2863-70.

84. Asgari E, Le Friec G, Yamamoto H, Perucha E, Sacks SS, Köhl J, et al. C3a modulates IL-1 $\beta$ secretion in human monocytes by regulating ATP efflux and subsequent NLRP3 inflammasome activation. Blood (2013) 122:3473-81. doi:10.1182/blood-2013-05-502229

85. Takabayashi T, Vannier E, Clark BD, Margolis NH, Dinarello CA, Burke JF, et al. A new biologic role for C3a and C3a desArg: regulation of TNF-alpha and IL-1 beta synthesis. J Immunol (1996) 1950(156):3455-60.

86. Fischer WH, Hugli TE. Regulation of B cell functions by C3a and C3a(desArg): suppression of TNF-alpha, IL-6, and the polyclonal immune response. J Immunol (1997) 1950(159):4279-86.

87. Peng Q, Li K, Anderson K, Farrar CA, Lu B, Smith RAG, et al. Local production and activation of complement up-regulates the allostimulatory function of dendritic cells through C3a-C3aR interaction. Blood (2008) 111:2452-61. doi:10.1182/blood-2007-06-095018

88. Ghannam A, Fauquert J-L, Thomas C, Kemper C, Drouet C. Human complement $\mathrm{C} 3$ deficiency: Th1 induction requires $\mathrm{T}$ cell-derived complement $\mathrm{C} 3 \mathrm{a}$ and CD46 activation. Mol Immunol (2014) 58:98-107. doi:10.1016/j.molimm. 2013.11.010

89. Heeger PS, Kemper C. Novel roles of complement in T effector cell regulation. Immunobiology (2012) 217:216-24. doi:10.1016/j.imbio.2011.06.004

90. Goligorsky MS, Patschan D, Kuo M-C. Weibel-Palade bodies - sentinels of acute stress. Nat Rev Nephrol (2009) 5:423-6. doi:10.1038/nrneph.2009.87

91. Sadler JE. Biochemistry and genetics of von Willebrand factor. Annu Rev Biochem (1998) 67:395-424. doi:10.1146/annurev.biochem.67.1.395

92. del Conde I. Platelet activation leads to activation and propagation of the complement system. J Exp Med (2005) 201:871-9. doi:10.1084/jem.20041497

93. Morigi M, Galbusera M, Gastoldi S, Locatelli M, Buelli S, Pezzotta A, et al. Alternative pathway activation of complement by shiga toxin promotes exuberant C3a formation that triggers microvascular thrombosis. J Immunol (2011) 187:172-80. doi:10.4049/jimmunol.1100491

94. Gerard NP, Gerard C. The chemotactic receptor for human C5a anaphylatoxin. Nature (1991) 349:614-7. doi:10.1038/349614a0

95. Perianayagam MC, Balakrishnan VS, King AJ, Pereira BJG, Jaber BL. C5a delays apoptosis of human neutrophils by a phosphatidylinositol 3-kinasesignaling pathway. Kidney Int (2002) 61:456-63. doi:10.1046/j.1523-1755. 2002.00139.x

96. la Sala A, Gadina M, Kelsall BL. G(i)-protein-dependent inhibition of IL-12 production is mediated by activation of the phosphatidylinositol 3-kinaseprotein 3 kinase B/Akt pathway and JNK. J Immunol (2005) 1950(175):2994-9. doi:10.4049/jimmunol.175.5.2994

97. Jiang H, Kuang Y, Wu Y, Xie W, Simon MI, Wu D. Roles of phospholipase C beta2 in chemoattractant-elicited responses. Proc Natl Acad Sci U S A (1997) 94:7971-5. doi:10.1073/pnas.94.15.7971

98. Mullmann TJ, Siegel MI, Egan RW, Billah MM. Complement C5a activation of phospholipase D in human neutrophils. A major route to the production of phosphatidates and diglycerides. J Immunol (1990) 1950(144):1901-8.

99. Buhl AM, Avdi N, Worthen GS, Johnson GL. Mapping of the C5a receptor signal transduction network in human neutrophils. Proc Natl Acad Sci U S A (1994) 91:9190-4. doi:10.1073/pnas.91.19.9190

100. Aksamit RR, Falk W, Leonard EJ. Chemotaxis by mouse macrophage cell lines. J Immunol (1981) 1950(126):2194-9.

101. Ehrengruber MU, Geiser T, Deranleau DA. Activation of human neutrophils by C3a and C5A. Comparison of the effects on shape changes, chemotaxis, secretion, and respiratory burst. FEBS Lett (1994) 346:181-4. doi:10.1016/ 0014-5793(94)00463-3

102. Lett-Brown MA, Leonard EJ. Histamine-induced inhibition of normal human basophil chemotaxis to C5a. J Immunol (1977) 1950(118):815-8.

103. Markiewski MM, DeAngelis RA, Benencia F, Ricklin-Lichtsteiner SK, Koutoulaki A, Gerard C, et al. Modulation of the antitumor immune response by complement. Nat Immunol (2008) 9:1225-35. doi:10.1038/ni.1655

104. Nataf S, Davoust N, Ames RS, Barnum SR. Human T cells express the C5a receptor and are chemoattracted to C5a. J Immunol (1999) 1950(162):4018-23.

105. Ottonello L, Corcione A, Tortolina G, Airoldi I, Albesiano E, Favre A, et al. rC5a directs the in vitro migration of human memory and naive tonsillar $B$ lymphocytes: implications for B cell trafficking in secondary lymphoid tissues. J Immunol (1999) 1950(162):6510-7.

106. Lalli PN, Strainic MG, Lin F, Medof ME, Heeger PS. Decay accelerating factor can control $\mathrm{T}$ cell differentiation into IFN-gamma-producing effector cells via regulating local C5a-induced IL-12 production. J Immunol (2007) 1950(179):5793-802. doi:10.4049/jimmunol.179.9.5793

107. Czermak BJ, Sarma V, Pierson CL, Warner RL, Huber-Lang M, Bless NM, et al. Protective effects of C5a blockade in sepsis. Nat Med (1999) 5:788-92. doi:10.1038/10512

108. Cortright DN, Meade R, Waters SM, Chenard BL, Krause JE. C5a, but not C3a, increases VEGF secretion in ARPE-19 human retinal pigment epithelial cells. Curr Eye Res (2009) 34:57-61. doi:10.1080/02713680802546658

109. Jain U, Cao Q, Thomas NA, Woodruff TM, Schwaeble WJ, Stover CM, et al. Properdin provides protection from Citrobacter rodentium-induced intestinal inflammation in a C5a/IL-6-dependent manner. J Immunol (2015) 1950(194):3414-21. doi:10.4049/jimmunol.1401814

110. Cui W, Lapointe M, Gauvreau D, Kalant D, Cianflone K. Recombinant C3adesArg/acylation stimulating protein (ASP) is highly bioactive: a critical evaluation of C5L2 binding and 3T3-L1 adipocyte activation. Mol Immunol (2009) 46:3207-17. doi:10.1016/j.molimm.2009.08.013

111. Cain SA, Monk PN. The orphan receptor C5L2 has high affinity binding sites for complement fragments C5a and C5a des-Arg(74). J Biol Chem (2002) 277:7165-9. doi:10.1074/jbc.C100714200

112. Okinaga S, Slattery D, Humbles A, Zsengeller Z, Morteau O, Kinrade MB, et al. C5L2, a nonsignaling C5A binding protein. Biochemistry (2003) 42:9406-15. doi:10.1021/bi034489v

113. Bamberg CE, Mackay CR, Lee H, Zahra D, Jackson J, Lim YS, et al. The C5a receptor $(\mathrm{C} 5 \mathrm{aR}) \mathrm{C} 5 \mathrm{~L} 2$ is a modulator of $\mathrm{C} 5 \mathrm{aR}$-mediated signal transduction. J Biol Chem (2010) 285:7633-44. doi:10.1074/jbc.M109.092106

114. Wang R, Lu B, Gerard C, Gerard NP. Disruption of the complement anaphylatoxin receptor C5L2 exacerbates inflammation in allergic contact dermatitis. J Immunol (2013) 1950(191):4001-9. doi:10.4049/jimmunol.1301626

115. Gerard NP, Lu B, Liu P, Craig S, Fujiwara Y, Okinaga S, et al. An antiinflammatory function for the complement anaphylatoxin C5a-binding protein, C5L2. J Biol Chem (2005) 280:39677-80. doi:10.1074/jbc.C500287200

116. Vijayan S, Asare Y, Grommes J, Soehnlein O, Lutgens E, Shagdarsuren G, et al. High expression of C5L2 correlates with high proinflammatory cytokine expression in advanced human atherosclerotic plaques. Am J Pathol (2014) 184:2123-33. doi:10.1016/j.ajpath.2014.04.004

117. Poursharifi P, Lapointe M, Pétrin D, Devost D, Gauvreau D, Hébert TE, et al. C5L2 and C5aR interaction in adipocytes and macrophages: insights into adipoimmunology. Cell Signal (2013) 25:910-8. doi:10.1016/j.cellsig. 2012.12.010

118. Hsu W-C, Yang F-C, Lin C-H, Hsieh S-L, Chen N-J. C5L2 is required for C5a-triggered receptor internalization and ERK signaling. Cell Signal (2014) 26:1409-19. doi:10.1016/j.cellsig.2014.02.021

119. DeFea KA, Zalevsky J, Thoma MS, Déry O, Mullins RD, Bunnett NW. betaarrestin-dependent endocytosis of proteinase-activated receptor 2 is required for intracellular targeting of activated ERK1/2. J Cell Biol (2000) 148:1267-81. doi:10.1083/jcb.148.6.1267

120. DeWire SM, Ahn S, Lefkowitz RJ, Shenoy SK. $\beta$-arrestins and cell signaling. Annu Rev Physiol (2007) 69:483-510. doi:10.1146/annurev.physiol.69.022405. 154749

121. Zhang X, Kimura Y, Fang C, Zhou L, Sfyroera G, Lambris JD, et al. Regulation of toll-like receptor-mediated inflammatory response by complement in vivo. Blood (2007) 110:228-36. doi:10.1182/blood-2006-12-063636

122. Harokopakis E, Albzreh MH, Martin MH, Hajishengallis G. TLR2 transmodulates monocyte adhesion and transmigration via Rac1- and PI3K-mediated 
inside-out signaling in response to Porphyromonas gingivalis fimbriae. J Immunol (2006) 1950(176):7645-56. doi:10.4049/jimmunol.176.12.7645

123. Kagan JC, Medzhitov R. Phosphoinositide-mediated adaptor recruitment controls toll-like receptor signaling. Cell (2006) 125:943-55. doi:10.1016/j.cell. 2006.03.047

124. Koleva M, Schlaf G, Landmann R, Götze O, Jungermann K, Schieferdecker HL. Induction of anaphylatoxin C5a receptors in rat hepatocytes by lipopolysaccharide in vivo: mediation by interleukin-6 from kupffer cells. Gastroenterology (2002) 122:697-708. doi:10.1053/gast.2002.31883

125. Hawlisch H, Belkaid Y, Baelder R, Hildeman D, Gerard C, Köhl J. C5a negatively regulates toll-like receptor 4 -induced immune responses. Immunity (2005) 22:415-26. doi:10.1016/j.immuni.2005.02.006

126. Rudilla F, Fayolle C, Casares N, Durantez M, Arribillaga L, Lozano T, et al. Combination of a TLR4 ligand and anaphylatoxin C5a for the induction of antigen-specific cytotoxic T cell responses. Vaccine (2012) 30:2848-58. doi:10. 1016/j.vaccine.2012.02.052

127. Zaal A, Lissenberg-Thunnissen SN, van Schijndel G, Wouters D, van Ham SM, ten Brinke A. Crosstalk between toll like receptors and C5a receptor in human monocyte derived DCs suppress inflammatory cytokine production. Immunobiology (2013) 218:175-80. doi:10.1016/j.imbio.2012.02.014

128. Pepys MB. Role of complement in induction of antibody production in vivo effect of cobra factor and other C3-reactive agents on thymus-dependent and thymus-independent antibody responses. J Exp Med (1974) 140:126-45. doi:10.1084/jem.140.1.126

129. Pepys MB, Butterworth AE. Inhibition by C3 fragments of C3-dependent rosette formation and antigen-induced lymphocyte transformation. Clin Exp Immunol (1974) 18:273-82.

130. Matsumoto AK, Martin DR, Carter RH, Klickstein LB, Ahearn JM, Fearon DT. Functional dissection of the CD21/CD19/TAPA-1/Leu-13 complex of B lymphocytes. J Exp Med (1993) 178:1407-17. doi:10.1084/jem.178.4.1407

131. Cherukuri A, Cheng PC, Pierce SK. The role of the CD19/CD21 complex in $\mathrm{B}$ cell processing and presentation of complement-tagged antigens. J Immunol (2001) 1950(167):163-72. doi:10.4049/jimmunol.167.1.163

132. Klaus GG, Humphrey JH. A re-evaluation of the role of $\mathrm{C} 3$ in B-cell activation. Immunol Today (1986) 7:163-5. doi:10.1016/0167-5699(86)90165-9

133. Fang Y, Xu C, Fu Y-X, Holers VM, Molina H. Expression of complement receptors 1 and 2 on follicular dendritic cells is necessary for the generation of a strong antigen-specific IgG response. J Immunol (1998) 160:5273-9.

134. Dempsey PW, Allison ME, Akkaraju S, Goodnow CC, Fearon DT. C3d of complement as a molecular adjuvant: bridging innate and acquired immunity. Science (1996) 271:348-50. doi:10.1126/science.271.5247.348

135. Brodeur SR, Angelini F, Bacharier LB, Blom AM, Mizoguchi E, Fujiwara H, et al. C4b-binding protein (C4BP) activates $\mathrm{B}$ cells through the $\mathrm{CD} 40$ receptor. Immunity (2003) 18:837-48. doi:10.1016/S1074-7613(03)00149-3

136. Chatterjee P, Agyemang AF, Alimzhanov MB, Degn S, Tsiftsoglou SA, Alicot $\mathrm{E}$, et al. Complement $\mathrm{C} 4$ maintains peripheral B-cell tolerance in a myeloid cell dependent manner. Eur J Immunol (2013) 43:2441-50. doi:10.1002/eji. 201343412

137. Del Nagro CJ, Kolla RV, Rickert RC. A critical role for complement C3d and the $\mathrm{B}$ cell coreceptor (CD19/CD21) complex in the initiation of inflammatory arthritis. J Immunol (2005) 175:5379-89. doi:10.4049/jimmunol.175.8.5379

138. Lyubchenko T, Dal Porto JM, Holers VM, Cambier JC. Cutting edge: complement (C3d)-linked antigens break B cell anergy. J Immunol (2007) 1950(179):2695-9. doi:10.4049/jimmunol.179.5.2695

139. Hundgeburth LC, Wunsch M, Rovituso D, Recks MS, Addicks K, Lehmann $\mathrm{PV}$, et al. The complement system contributes to the pathology of experimental autoimmune encephalomyelitis by triggering demyelination and modifying the antigen-specific T and B cell response. Clin Immunol (2013) 146:155-64. doi:10.1016/j.clim.2012.12.007

140. Kemper C, Atkinson JP. T-cell regulation: with complements from innate immunity. Nat Rev Immunol (2007) 7:9-18. doi:10.1038/nri1994

141. Kemper C, Chan AC, Green JM, Brett KA, Murphy KM, Atkinson JP. Activation of human CD4+ cells with CD3 and CD46 induces a T-regulatory cell 1 phenotype. Nature (2003) 421:388-92. doi:10.1038/nature01315

142. Morgan BP, Marchbank KJ, Longhi MP, Harris CL, Gallimore AM. Complement: central to innate immunity and bridging to adaptive responses. Immunol Lett (2005) 97:171-9. doi:10.1016/j.imlet.2004.11.010

143. Baudino L, Sardini A, Ruseva MM, Fossati-Jimack L, Cook HT, Scott D, et al. C3 opsonization regulates endocytic handling of apoptotic cells resulting in enhanced T-cell responses to cargo-derived antigens. Proc Natl Acad Sci U S A (2014) 111:1503-8. doi:10.1073/pnas.1316877111

144. Mueller-Ortiz SL, Morales JE, Wetsel RA. The receptor for the complement C3a anaphylatoxin (C3aR) provides host protection against Listeria monocytogenes-induced apoptosis. J Immunol (2014) 193:1278-89. doi:10. 4049/jimmunol.1302787

145. Kwan W, van der Touw W, Paz-Artal E, Li MO, Heeger PS. Signaling through $\mathrm{C} 5 \mathrm{a}$ receptor and $\mathrm{C} 3 \mathrm{a}$ receptor diminishes function of murine natural regulatory T cells. J Exp Med (2013) 210:257-68. doi:10.1084/jem.20121525

146. Strainic MG, Shevach EM, An F, Lin F, Medof ME. Absence of signaling into $\mathrm{CD} 4^{+}$cells via $\mathrm{C} 3 \mathrm{aR}$ and $\mathrm{C} 5 \mathrm{aR}$ enables autoinductive TGF- $\beta 1$ signaling and induction of Foxp3 ${ }^{+}$regulatory T cells. Nat Immunol (2013) 14:162-71. doi:10.1038/ni.2499

147. Le Friec G, Sheppard D, Whiteman P, Karsten CM, Shamoun SA-T, Laing A, et al. The CD46-Jagged 1 interaction is critical for human TH1 immunity. Nat Immunol (2012) 13:1213-21. doi:10.1038/ni.2454

148. Ghannam A, Pernollet M, Fauquert J-L, Monnier N, Ponard D, Villiers M-B, et al. Human C3 deficiency associated with impairments in dendritic cell differentiation, memory B cells, and regulatory T cells. J Immunol (2008) 1950(181):5158-66. doi:10.4049/jimmunol.181.7.5158

149. Kolev M, Le Friec G, Kemper C. The role of complement in CD4+ T cell homeostasis and effector functions. Semin Immunol (2013) 25:12-9. doi:10. 1016/j.smim.2013.04.012

150. Cardone J, Le Friec G, Vantourout P, Roberts A, Fuchs A, Jackson I, et al. Complement regulator CD46 temporally regulates cytokine production by conventional and unconventional T cells. Nat Immunol (2010) 11:862-71. doi:10.1038/ni.1917

151. Heeger PS, Lalli PN, Lin F, Valujskikh A, Liu J, Muqim N, et al. Decayaccelerating factor modulates induction of T cell immunity. J Exp Med (2005) 201:1523-30. doi:10.1084/jem.20041967

152. Liu J, Miwa T, Hilliard B, Chen Y, Lambris JD, Wells AD, et al. The complement inhibitory protein DAF (CD55) suppresses T cell immunity in vivo. J Exp Med (2005) 201:567-77. doi:10.1084/jem.20040863

153. Dunkelberger JR, Song W-C. Complement and its role in innate and adaptive immune responses. Cell Res (2009) 20:34-50. doi:10.1038/cr.2009.139

154. Lipp AM, Juhasz K, Paar C, Ogris C, Eckerstorfer P, Thuenauer R, et al. Lck mediates signal transmission from CD59 to the TCR/CD3 pathway in jurkat T cells. PLoS One (2014) 9:e85934. doi:10.1371/journal.pone.0085934

155. Wagner C, Ochmann C, Schoels M, Giese T, Stegmaier S, Richter R, et al. The complement receptor 1, CR1 (CD35), mediates inhibitory signals in human T-lymphocytes. Mol Immunol (2006) 43:643-51. doi:10.1016/j.molimm.2005. 04.006

156. Tam JCH, Bidgood SR, McEwan WA, James LC. Intracellular sensing of complement C3 activates cell autonomous immunity. Science (2014) 345:1256070. doi:10.1126/science. 1256070

157. Lambris JD, Ricklin D, Geisbrecht BV. Complement evasion by human pathogens. Nat Rev Microbiol (2008) 6:132-42. doi:10.1038/nrmicro1824

158. Zipfel PF, Würzner R, Skerka C. Complement evasion of pathogens: common strategies are shared by diverse organisms. Mol Immunol (2007) 44:3850-7. doi:10.1016/j.molimm.2007.06.149

159. Schneider MC, Exley RM, Chan H, Feavers I, Kang Y-H, Sim RB, et al. Functional significance of factor $\mathrm{H}$ binding to Neisseria meningitidis. J Immunol (2006) 176:7566-75. doi:10.4049/jimmunol.176.12.7566

160. Berggård K, Johnsson E, Mooi FR, Lindahl G. Bordetella pertussis binds the human complement regulator C4BP: role of filamentous hemagglutinin. Infect Immun (1997) 65:3638-43.

161. Ho DK, Skurnik M, Blom AM, Meri S. Yersinia pestis ail recruitment of C4b-binding protein leads to factor I-mediated inactivation of covalently and noncovalently bound C4b: immunity to infection. Eur J Immunol (2014) 44:742-51. doi:10.1002/eji.201343552

162. Lewis LA, Ngampasutadol J, Wallace R, Reid JEA, Vogel U, Ram S. The meningococcal vaccine candidate neisserial surface protein $\mathrm{A}(\mathrm{NspA})$ binds to factor $\mathrm{H}$ and enhances meningococcal resistance to complement. PLoS Pathog (2010) 6:e1001027. doi:10.1371/journal.ppat.1001027

163. Ermert D, Weckel A, Agarwal V, Frick I-M, Björck L, Blom AM. Binding of complement inhibitor C4b-binding protein to a highly virulent Streptococcus pyogenes $\mathrm{M} 1$ strain is mediated by protein $\mathrm{H}$ and enhances adhesion to and invasion of endothelial cells. J Biol Chem (2013) 288:32172-83. doi:10.1074/ jbc.M113.502955 
164. Bhattacharjee A, Oeemig JS, Kolodziejczyk R, Meri T, Kajander T, Lehtinen MJ, et al. Structural basis for complement evasion by lyme disease pathogen Borrelia burgdorferi. J Biol Chem (2013) 288:18685-95. doi:10.1074/jbc.M113. 459040

165. Meri T, Amdahl H, Lehtinen MJ, Hyvärinen S, McDowell JV, Bhattacharjee A, et al. Microbes bind complement inhibitor factor $\mathrm{H}$ via a common site. PLoS Pathog (2013) 9:e1003308. doi:10.1371/journal.ppat.1003308

166. Ngampasutadol J, Ram S, Gulati S, Agarwal S, Li C, Visintin A, et al. Human factor $\mathrm{H}$ interacts selectively with Neisseria gonorrhoeae and results in speciesspecific complement evasion. J Immunol (2008) 1950(180):3426-35. doi:10. 4049/jimmunol.180.5.3426

167. Schneider MC, Prosser BE, Caesar JJE, Kugelberg E, Li S, Zhang Q, et al. Neisseria meningitidis recruits factor $\mathrm{H}$ using protein mimicry of host carbohydrates. Nature (2009) 458:890-3. doi:10.1038/nature07769

168. Miller DP, Bell JK, McDowell JV, Conrad DH, Burgner JW, Héroux A, et al. Structure of factor H-binding protein B (FhbB) of the periopathogen, Treponema denticola. J Biol Chem (2012) 287:12715-22. doi:10.1074/jbc.M112. 339721

169. Foster TJ. Immune evasion by Staphylococci. Nat Rev Microbiol (2005) 3:948-58. doi:10.1038/nrmicro1289

170. Hair PS, Foley CK, Krishna NK, Nyalwidhe JO, Geoghegan JA, Foster TJ, et al. Complement regulator $\mathrm{C} 4 \mathrm{BP}$ binds to Staphylococcus aureus surface proteins SdrE and Bbp inhibiting bacterial opsonization and killing. Results Immunol (2013) 3:114-21. doi:10.1016/j.rinim.2013.10.004

171. Sharp JA, Echague CG, Hair PS, Ward MD, Nyalwidhe JO, Geoghegan JA, et al. Staphylococcus aureus surface protein SdrE binds complement regulator factor $\mathrm{H}$ as an immune evasion tactic. PLoS One (2012) 7:e38407. doi:10.1371/ journal.pone.0038407

172. Liszewski MK, Leung MK, Hauhart R, Buller RML, Bertram P, Wang X, et al. Structure and regulatory profile of the monkeypox inhibitor of complement: comparison to homologs in vaccinia and variola and evidence for dimer formation. J Immunol (2006) 176:3725-34. doi:10.4049/jimmunol.176. 6.3725

173. Lubinski JM, Wang L, Soulika AM, Burger R, Wetsel RA, Colten H, et al. Herpes simplex virus type 1 glycoprotein gC mediates immune evasion in vivo. J Virol (1998) 72:8257-63.

174. Rooijakkers SHM, van Strijp JAG. Bacterial complement evasion. Mol Immunol (2007) 44:23-32. doi:10.1016/j.molimm.2006.06.011

175. Fraga TR, Courrol DDS, Castiblanco-Valencia MM, Hirata IY, Vasconcellos SA, Juliano L, et al. Immune evasion by pathogenic Leptospira strains: the secretion of proteases that directly cleave complement proteins. J Infect Dis (2014) 209:876-86. doi:10.1093/infdis/jit569

176. Rooijakkers SHM, van Wamel WJB, Ruyken M, van Kessel KPM, van Strijp JAG. Anti-opsonic properties of staphylokinase. Microbes Infect (2005) 7:476-84. doi:10.1016/j.micinf.2004.12.014

177. Jusko M, Potempa J, Kantyka T, Bielecka E, Miller HK, Kalinska M, et al. Staphylococcal proteases aid in evasion of the human complement system. J Innate Immun (2014) 6:31-46. doi:10.1159/000351458

178. Laarman AJ, Ruyken M, Malone CL, van Strijp JAG, Horswill AR, Rooijakkers SHM. Staphylococcus aureus metalloprotease aureolysin cleaves complement C3 to mediate immune evasion. J Immunol (2011) 1950(186):6445-53. doi:10. 4049/jimmunol.1002948

179. Del Tordello E, Vacca I, Ram S, Rappuoli R, Serruto D. Neisseria meningitidis NalP cleaves human complement C3, facilitating degradation of $\mathrm{C} 3 \mathrm{~b}$ and survival in human serum. Proc Natl Acad Sci U S A (2014) 111:427-32. doi:10. 1073/pnas.1321556111

180. Agarwal S, Vasudhev S, DeOliveira RB, Ram S. Inhibition of the classical pathway of complement by meningococcal capsular polysaccharides. J Immunol (2014) 193:1855-63. doi:10.4049/jimmunol.1303177

181. Johnson JB, Borisevich V, Rockx B, Parks GD. A novel factor I activity in Nipah virus inhibits human complement pathways through cleavage of C3b. J Virol (2015) 89:989-98. doi:10.1128/JVI.02427-14

182. Hammel M, Sfyroera G, Ricklin D, Magotti P, Lambris JD, Geisbrecht BV. A structural basis for complement inhibition by Staphylococcus aureus. Nat Immunol (2007) 8:430-7. doi:10.1038/ni1450

183. Haspel N, Ricklin D, Geisbrecht BV, Kavraki LE, Lambris JD. Electrostatic contributions drive the interaction between Staphylococcus aureus protein Efb-C and its complement target C3d. Protein Sci (2008) 17:1894-906. doi:10. $1110 /$ ps.036624.108
184. Koch TK, Reuter M, Barthel D, Böhm S, van den Elsen J, Kraiczy P, et al Staphylococcus aureus proteins Sbi and Efb recruit human plasmin to degrade complement C3 and C3b. PLoS One (2012) 7:e47638. doi:10.1371/journal. pone. 0047638

185. Lee LYL, Liang X, Hook M, Brown EL. Identification and characterization of the C3 binding domain of the Staphylococcus aureus extracellular fibrinogenbinding protein (Efb). J Biol Chem (2004) 279:50710-6. doi:10.1074/jbc. M408570200

186. Lee LY, Höök M, Haviland D, Wetsel RA, Yonter EO, Syribeys P, et al. Inhibition of complement activation by a secreted Staphylococcus aureus protein. J Infect Dis (2004) 190:571-9. doi:10.1086/422259

187. Hammel M, Sfyroera G, Pyrpassopoulos S, Ricklin D, Ramyar KX, Pop M, et al. Characterization of Ehp, a secreted complement inhibitory protein from Staphylococcus aureus. J Biol Chem (2007) 282:30051-61. doi:10.1074/jbc. M704247200

188. Haupt K, Reuter M, van den Elsen J, Burman J, Hälbich S, Richter J, et al. The Staphylococcus aureus protein Sbi acts as a complement inhibitor and forms a tripartite complex with host complement factor $\mathrm{H}$ and C3b. PLoS Pathog (2008) 4:e1000250. doi:10.1371/journal.ppat.1000250

189. Upadhyay A, Burman JD, Clark EA, Leung E, Isenman DE, van den Elsen JMH, et al. Structure-function analysis of the C3 binding region of Staphylococcus aureus immune subversion protein Sbi. J Biol Chem (2008) 283:22113-20. doi:10.1074/jbc.M802636200

190. Jongerius I, Köhl J, Pandey MK, Ruyken M, van Kessel KPM, van Strijp JAG, et al. Staphylococcal complement evasion by various convertaseblocking molecules. J Exp Med (2007) 204:2461-71. doi:10.1084/jem. 20070818

191. Garcia BL, Ramyar KX, Tzekou A, Ricklin D, McWhorter WJ, Lambris JD, et al. Molecular basis for complement recognition and inhibition determined by crystallographic studies of the staphylococcal complement inhibitor (SCIN) bound to C3c and C3b. J Mol Biol (2010) 402:17-29. doi:10.1016/j.jmb.2010. 07.029

192. Garcia BL, Ramyar KX, Ricklin D, Lambris JD, Geisbrecht BV. Advances in understanding the structure, function, and mechanism of the SCIN and Efb families of staphylococcal immune evasion proteins. Adv Exp Med Biol (2012) 946:113-33. doi:10.1007/978-1-4614-0106-3 7

193. Ricklin D, Tzekou A, Garcia BL, Hammel M, McWhorter WJ, Sfyroera G, et al. A molecular insight into complement evasion by the staphylococcal complement inhibitor protein family. J Immunol (2009) 1950(183):2565-74. doi:10.4049/jimmunol.0901443

194. Rooijakkers SHM, Wu J, Ruyken M, van Domselaar R, Planken KL, Tzekou A, et al. Structural and functional implications of the alternative complement pathway C3 convertase stabilized by a staphylococcal inhibitor. Nat Immunol (2009) 10:721-7. doi:10.1038/ni.1756

195. Jongerius I, Puister M, Wu J, Ruyken M, van Strijp JAG, Rooijakkers SHM Staphylococcal complement inhibitor modulates phagocyte responses by dimerization of convertases. J Immunol (2010) 1950(184):420-5. doi:10.4049/ jimmunol.0902865

196. Ricklin D, Lambris JD. Compstatin: a complement inhibitor on its way to clinical application. Adv Exp Med Biol (2008) 632:273-92. doi:10.1111/eci. 12419

197. Serruto D, Rappuoli R, Scarselli M, Gros P, van Strijp JAG. Molecular mechanisms of complement evasion: learning from staphylococci and meningococci. Nat Rev Microbiol (2010) 8:393-9. doi:10.1038/nrmicro2366

198. Leffler J, Bengtsson AA, Blom AM. The complement system in systemic lupus erythematosus: an update. Ann Rheum Dis (2014) 73:1601-6. doi:10.1136/ annrheumdis-2014-205287

199. Schejbel L, Skattum L, Hagelberg S, Åhlin A, Schiller B, Berg S, et al. Molecular basis of hereditary C1q deficiency - revisited: identification of several novel disease-causing mutations. Genes Immun (2011) 12:626-34. doi:10.1038/gene. 2011.39

200. Yin Y, Wu X, Shan G, Zhang X. Diagnostic value of serum anti-C1q antibodies in patients with lupus nephritis: a meta-analysis. Lupus (2012) 21:1088-97. doi: $10.1177 / 0961203312451202$

201. Vanhecke D, Roumenina LT, Wan H, Osthoff M, Schaller M, Trendelenburg $\mathrm{M}$. Identification of a major linear $\mathrm{Clq}$ epitope allows detection of systemic lupus erythematosus anti-C1q antibodies by a specific peptide-based enzymelinked immunosorbent assay. Arthritis Rheum (2012) 64:3706-14. doi:10. 1002/art.34605 
202. Radanova M, Vasilev V, Deliyska B, Kishore U, Ikonomov V, Ivanova D. Anti-C1q autoantibodies specific against the globular domain of the C1qBchain from patient with lupus nephritis inhibit C1q binding to IgG and CRP. Immunobiology (2012) 217:684-91. doi:10.1016/j.imbio.2011.11.007

203. Mahler M, van Schaarenburg RA, Trouw LA. Anti-C1q autoantibodies, novel tests, and clinical consequences. Front Immunol (2013) 4:117. doi:10.3389/ fimmu.2013.00117

204. Trouw LA, Groeneveld TWL, Seelen MA, Duijs JMGJ, Bajema IM, Prins FA, et al. Anti-C1q autoantibodies deposit in glomeruli but are only pathogenic in combination with glomerular $\mathrm{Clq}$-containing immune complexes. J Clin Invest (2004) 114:679-88. doi:10.1172/JCI200421075

205. Bigler C, Schaller M, Perahud I, Osthoff M, Trendelenburg M. Autoantibodies against complement $\mathrm{C} 1 \mathrm{q}$ specifically target $\mathrm{C} 1 \mathrm{q}$ bound on early apoptotic cells. J Immunol (2009) 1950(183):3512-21. doi:10.4049/jimmunol.0803573

206. Noris M, Remuzzi G. Atypical hemolytic-uremic syndrome. N Engl J Med (2009) 361:1676-87. doi:10.1056/NEJMra0902814

207. Roumenina LT, Loirat C, Dragon-Durey M-A, Halbwachs-Mecarelli L, SautesFridman C, Fremeaux-Bacchi V. Alternative complement pathway assessment in patients with atypical HUS. J Immunol Methods (2011) 365:8-26. doi:10. 1016/j.jim.2010.12.020

208. Fakhouri F, Frémeaux-Bacchi V, Noël L-H, Cook HT, Pickering MC. C3 glomerulopathy: a new classification. Nat Rev Nephrol (2010) 6:494-9. doi:10. 1038/nrneph.2010.85

209. Sethi S, Fervenza FC. Membranoproliferative glomerulonephritis - a new look at an old entity. N Engl J Med (2012) 366:1119-31. doi:10.1056/ NEJMra1 108178

210. Malina M, Roumenina LT, Seeman T, Le Quintrec M, Dragon-Durey M-A, Schaefer F, et al. Genetics of hemolytic uremic syndromes. Presse Méd (2012) 1983(41):e105-14. doi:10.1016/j.lpm.2011.10.028

211. Ferreira VP, Herbert AP, Cortés C, McKee KA, Blaum BS, Esswein ST, et al. The binding of factor $\mathrm{H}$ to a complex of physiological polyanions and $\mathrm{C} 3 \mathrm{~b}$ on cells is impaired in atypical hemolytic uremic syndrome. J Immunol (2009) 1950(182):7009-18. doi:10.4049/jimmunol.0804031

212. Lehtinen MJ, Rops AL, Isenman DE, van der Vlag J, Jokiranta TS. Mutations of factor $\mathrm{H}$ impair regulation of surface-bound $\mathrm{C} 3 \mathrm{~b}$ by three mechanisms in atypical hemolytic uremic syndrome. J Biol Chem (2009) 284:15650-8. doi:10.1074/jbc.M900814200

213. Manuelian T, Hellwage J, Meri S, Caprioli J, Noris M, Heinen S, et al. Mutations in factor $\mathrm{H}$ reduce binding affinity to $\mathrm{C} 3 \mathrm{~b}$ and heparin and surface attachment to endothelial cells in hemolytic uremic syndrome. J Clin Invest (2003) 111:1181-90. doi:10.1172/JCI200316651

214. Bienaime F, Dragon-Durey M-A, Regnier CH, Nilsson SC, Kwan WH, Blouin $\mathrm{J}$, et al. Mutations in components of complement influence the outcome of factor I-associated atypical hemolytic uremic syndrome. Kidney Int (2010) 77:339-49. doi:10.1038/ki.2009.472

215. Nilsson SC, Kalchishkova N, Trouw LA, Fremeaux-Bacchi V, Villoutreix BO, Blom AM. Mutations in complement factor I as found in atypical hemolytic uremic syndrome lead to either altered secretion or altered function of factor I. Eur J Immunol (2010) 40:172-85. doi:10.1002/eji.200939280

216. Frémeaux-Bacchi V, Miller EC, Liszewski MK, Strain L, Blouin J, Brown $\mathrm{AL}$, et al. Mutations in complement $\mathrm{C} 3$ predispose to development of atypical hemolytic uremic syndrome. Blood (2008) 112:4948-52. doi:10.1182/ blood-2008-01-133702

217. Goicoechea de Jorge E, Harris CL, Esparza-Gordillo J, Carreras L, Arranz EA, et al. Gain-of-function mutations in complement factor B are associated with atypical hemolytic uremic syndrome. Proc Natl Acad Sci U S A (2007) 104:240-5. doi:10.1073/pnas.0603420103

218. Marinozzi MC, Vergoz L, Rybkine T, Ngo S, Bettoni S, Pashov A, et al. Complement factor B mutations in atypical hemolytic uremic syndromedisease-relevant or benign? J Am Soc Nephrol (2014) 25:2053-65. doi:10.1681/ ASN.2013070796

219. Roumenina LT, Jablonski M, Hue C, Blouin J, Dimitrov JD, Dragon-Durey $\mathrm{M}-\mathrm{A}$, et al. Hyperfunctional C3 convertase leads to complement deposition on endothelial cells and contributes to atypical hemolytic uremic syndrome. Blood (2009) 114:2837-45. doi:10.1182/blood-2009-01-197640

220. Roumenina LT, Frimat M, Miller EC, Provot F, Dragon-Durey M-A, Bordereau $\mathrm{P}$, et al. A prevalent $\mathrm{C} 3$ mutation in aHUS patients causes a direct C3 convertase gain of function. Blood (2012) 119:4182-91. doi:10.1182/ blood-2011-10-383281
221. Schramm EC, Roumenina LT, Rybkine T, Chauvet S, Vieira-Martins P, Hue C, et al. Functional mapping of the interactions between complement C3 and regulatory proteins using atypical hemolytic uremic syndrome-associated mutations. Blood (2015) 125(15):2359-69. doi:10.1182/blood-2014-10-609073

222. Dragon-Durey M-A, Loirat C, Cloarec S, Macher M-A, Blouin J, Nivet H, et al. Anti-factor $\mathrm{H}$ autoantibodies associated with atypical hemolytic uremic syndrome. J Am Soc Nephrol (2005) 16:555-63. doi:10.1681/ASN.2004050380

223. Dragon-Durey M-A, Sethi SK, Bagga A, Blanc C, Blouin J, Ranchin B, et al. Clinical features of anti-factor $\mathrm{H}$ autoantibody-associated hemolytic uremic syndrome. J Am Soc Nephrol (2010) 21:2180-7. doi:10.1681/ASN. 2010030315

224. Józsi M, Licht C, Strobel S, Zipfel SLH, Richter H, Heinen S, et al. Factor $\mathrm{H}$ autoantibodies in atypical hemolytic uremic syndrome correlate with CFHR1/CFHR3 deficiency. Blood (2008) 111:1512-4. doi:10.1182/ blood-2007-09-109876

225. Blanc C, Roumenina LT, Ashraf Y, Hyvärinen S, Sethi SK, Ranchin B, et al. Overall neutralization of complement factor $\mathrm{H}$ by autoantibodies in the acute phase of the autoimmune form of atypical hemolytic uremic syndrome. J Immunol (2012) 1950(189):3528-37. doi:10.4049/jimmunol.1200679

226. Fremeaux-Bacchi V, Fakhouri F, Garnier A, Bienaimé F, Dragon-Durey M-A, Ngo S, et al. Genetics and outcome of atypical hemolytic uremic syndrome: a nationwide French series comparing children and adults. Clin J Am Soc Nephrol (2013) 8:554-62. doi:10.2215/CJN.04760512

227. Noris M, Caprioli J, Bresin E, Mossali C, Pianetti G, Gamba S, et al. Relative role of genetic complement abnormalities in sporadic and familial aHUS and their impact on clinical phenotype. Clin J Am Soc Nephrol (2010) 5:1844-59. doi:10.2215/CJN.02210310

228. Bresin E, Rurali E, Caprioli J, Sanchez-Corral P, Fremeaux-Bacchi V, Rodriguez de Cordoba S, et al. Combined complement gene mutations in atypical hemolytic uremic syndrome influence clinical phenotype. J Am Soc Nephrol (2013) 24:475-86. doi:10.1681/ASN.2012090884

229. Lemaire M, Frémeaux-Bacchi V, Schaefer F, Choi M, Tang WH, Le Quintrec $\mathrm{M}$, et al. Recessive mutations in DGKE cause atypical hemolytic-uremic syndrome. Nat Genet (2013) 45:531-6. doi:10.1038/ng.2590

230. Bruneau S, Néel M, Roumenina LT, Frimat M, Laurent L, Frémeaux-Bacchi $\mathrm{V}$, et al. Loss of DGKe induces endothelial cell activation and death independently of complement activation. Blood (2014) 125(6):1038-46. doi:10.1182/ blood-2014-06-579953

231. Rodríguez de Córdoba S, Hidalgo MS, Pinto S, Tortajada A. Genetics of atypical hemolytic uremic syndrome (aHUS). Semin Thromb Hemost (2014) 40:422-30. doi:10.1055/s-0034-1375296

232. Sansbury FH, Cordell HJ, Bingham C, Bromilow G, Nicholls A, Powell R, et al. Factors determining penetrance in familial atypical haemolytic uraemic syndrome. J Med Genet (2014) 51:756-64. doi:10.1136/jmedgenet-2014-102498

233. Frimat M, Tabarin F, Dimitrov JD, Poitou C, Halbwachs-Mecarelli L, Fremeaux-Bacchi V, et al. Complement activation by heme as a secondary hit for atypical hemolytic uremic syndrome. Blood (2013) 122:282-92. doi:10. 1182/blood-2013-03-489245

234. Pawluczkowycz AW, Lindorfer MA, Waitumbi JN, Taylor RP. Hematin promotes complement alternative pathway-mediated deposition of $\mathrm{C} 3$ activation fragments on human erythrocytes: potential implications for the pathogenesis of anemia in malaria. J Immunol (2007) 1950(179):5543-52. doi:10.4049/ jimmunol.179.8.5543

235. Dragon-Durey M-A, Blanc C, Marinozzi MC, van Schaarenburg RA, Trouw LA. Autoantibodies against complement components and functional consequences. Mol Immunol (2013) 56:213-21. doi:10.1016/j.molimm.2013. 05.009

236. Paixão-Cavalcante D, López-Trascasa M, Skattum L, Giclas PC, Goodship TH, de Córdoba SR, et al. Sensitive and specific assays for C3 nephritic factors clarify mechanisms underlying complement dysregulation. Kidney Int (2012) 82:1084-92. doi:10.1038/ki.2012.250

237. Servais A, Noël L-H, Roumenina LT, Le Quintrec M, Ngo S, Dragon-Durey M-A, et al. Acquired and genetic complement abnormalities play a critical role in dense deposit disease and other C3 glomerulopathies. Kidney Int (2012) 82:454-64. doi:10.1038/ki.2012.63

238. Martínez-Barricarte R, Heurich M, Valdes-Cañedo F, Vazquez-Martul E, Torreira E, Montes T, et al. Human C3 mutation reveals a mechanism of dense deposit disease pathogenesis and provides insights into complement activation and regulation. J Clin Invest (2010) 120:3702-12. doi:10.1172/JCI43343 
239. Zhang Y, Meyer NC, Wang K, Nishimura C, Frees K, Jones M, et al. Causes of alternative pathway dysregulation in dense deposit disease. Clin J Am Soc Nephrol (2012) 7:265-74. doi:10.2215/CJN.07900811

240. Chen Q, Wiesener M, Eberhardt HU, Hartmann A, Uzonyi B, Kirschfink M, et al. Complement factor H-related hybrid protein deregulates complement in dense deposit disease. J Clin Invest (2014) 124:145-55. doi:10.1172/JCI71866

241. Goicoechea de Jorge E, Caesar JJE, Malik TH, Patel M, Colledge M, Johnson $\mathrm{S}$, et al. Dimerization of complement factor H-related proteins modulates complement activation in vivo. Proc Natl Acad Sci U S A (2013) 110:4685-90. doi:10.1073/pnas.1219260110

242. Malik TH, Lavin PJ, Goicoechea de Jorge E, Vernon KA, Rose KL, Patel MP, et al. A hybrid CFHR3-1 gene causes familial C3 glomerulopathy. J Am Soc Nephrol (2012) 23:1155-60. doi:10.1681/ASN.2012020166

243. Gale DP, de Jorge EG, Cook HT, Martinez-Barricarte R, Hadjisavvas A, McLean AG, et al. Identification of a mutation in complement factor H-related protein 5 in patients of cypriot origin with glomerulonephritis. Lancet (2010) 376:794-801. doi:10.1016/S0140-6736(10)60670-8

244. Edwards AO, Ritter R, Abel KJ, Manning A, Panhuysen C, Farrer LA. Complement factor $\mathrm{H}$ polymorphism and age-related macular degeneration. Science (2005) 308:421-4. doi:10.1126/science.1110189

245. Hageman GS, Anderson DH, Johnson LV, Hancox LS, Taiber AJ, Hardisty $\mathrm{LI}$, et al. A common haplotype in the complement regulatory gene factor $\mathrm{H}$ (HF1/CFH) predisposes individuals to age-related macular degeneration. Proc Natl Acad Sci U S A (2005) 102:7227-32. doi:10.1073/pnas.0501536102

246. Haines JL, Hauser MA, Schmidt S, Scott WK, Olson LM, Gallins P, et al. Complement factor $\mathrm{H}$ variant increases the risk of age-related macular degeneration. Science (2005) 308:419-21. doi:10.1126/science.1110359

247. Klein RJ, Zeiss C, Chew EY, Tsai J-Y, Sackler RS, Haynes C, et al. Complement factor $\mathrm{H}$ polymorphism in age-related macular degeneration. Science (2005) 308:385-9. doi:10.1126/science.1109557

248. Lim LS, Mitchell P, Seddon JM, Holz FG, Wong TY. Age-related macular degeneration. Lancet (2012) 379:1728-38. doi:10.1016/S0140-6736(12) 60282-7

249. Shaw PX, Zhang L, Zhang M, Du H, Zhao L, Lee C, et al. Complement factor $\mathrm{H}$ genotypes impact risk of age-related macular degeneration by interaction with oxidized phospholipids. Proc Natl Acad Sci U S A (2012) 109:13757-62. doi:10.1073/pnas.1121309109

250. Weismann D, Hartvigsen K, Lauer N, Bennett KL, Scholl HPN, Charbel Issa $\mathrm{P}$, et al. Complement factor $\mathrm{H}$ binds malondialdehyde epitopes and protects from oxidative stress. Nature (2011) 478:76-81. doi:10.1038/nature10449

251. Seddon JM, Yu Y, Miller EC, Reynolds R, Tan PL, Gowrisankar S, et al. Rare variants in CFI, C3 and C9 are associated with high risk of advanced agerelated macular degeneration. Nat Genet (2013) 45:1366-70. doi:10.1038/ng. 2741

252. Skerka C, Chen Q, Fremeaux-Bacchi V, Roumenina LT. Complement factor $\mathrm{H}$ related proteins (CFHRs). Mol Immunol (2013) 56:170-80. doi:10.1016/j. molimm.2013.06.001

253. Hughes AE, Orr N, Esfandiary H, Diaz-Torres M, Goodship T, Chakravarthy U. A common CFH haplotype, with deletion of CFHR1 and CFHR3, is associated with lower risk of age-related macular degeneration. Nat Genet (2006) 38:1173-7. doi:10.1038/ng1890

254. Fritsche LG, Lauer N, Hartmann A, Stippa S, Keilhauer CN, Oppermann $\mathrm{M}$, et al. An imbalance of human complement regulatory proteins CFHR1, CFHR3 and factor $\mathrm{H}$ influences risk for age-related macular degeneration (AMD). Hum Mol Genet (2010) 19:4694-704. doi:10.1093/hmg/ddq399

255. Tortajada A, Yébenes H, Abarrategui-Garrido C, Anter J, García-Fernández JM, Martínez-Barricarte R, et al. C3 glomerulopathy-associated CFHR1 mutation alters FHR oligomerization and complement regulation. J Clin Invest (2013) 123:2434-46. doi:10.1172/JCI68280

256. Cho MS, Vasquez HG, Rupaimoole R, Pradeep S, Wu S, Zand B, et al. Autocrine effects of tumor-derived complement. Cell Rep (2014) 6:1085-95. doi:10.1016/j.celrep.2014.02.014

257. Corrales L, Ajona D, Rafail S, Lasarte JJ, Riezu-Boj JI, Lambris JD, et al. Anaphylatoxin C5a creates a favorable microenvironment for lung cancer progression. J Immunol (2012) 1950(189):4674-83. doi:10.4049/jimmunol. 1201654

258. Vadrevu SK, Chintala NK, Sharma SK, Sharma P, Cleveland C, Riediger L, et al. Complement $\mathrm{C} 5$ a receptor facilitates cancer metastasis by altering T-cell responses in the metastatic niche. Cancer Res (2014) 74:3454-65. doi:10.1158/ 0008-5472.CAN-14-0157

259. Surace L, Lysenko V, Fontana AO, Cecconi V, Janssen H, Bicvic A, et al. Complement is a central mediator of radiotherapy-induced tumor-specific immunity and clinical response. Immunity (2015) 42:767-77. doi:10.1016/j. immuni.2015.03.009

260. Ajona D, Castaño Z, Garayoa M, Zudaire E, Pajares MJ, Martinez A, et al. Expression of complement factor $\mathrm{H}$ by lung cancer cells: effects on the activation of the alternative pathway of complement. Cancer Res (2004) 64:6310-8. doi:10.1158/0008-5472.CAN-03-2328

261. Cui T, Chen Y, Knösel T, Yang L, Zöller K, Galler K, et al. Human complement factor $\mathrm{H}$ is a novel diagnostic marker for lung adenocarcinoma. Int J Oncol (2011) 39:161-8. doi:10.3892/ijo.2011.1010

262. Kinders R, Jones T, Root R, Bruce C, Murchison H, Corey M, et al. Complement factor $\mathrm{H}$ or a related protein is a marker for transitional cell cancer of the bladder. Clin Cancer Res (1998) 4:2511-20.

263. Riihilä PM, Nissinen LM, Ala-aho R, Kallajoki M, Grénman R, Meri S, et al. Complement factor $\mathrm{H}$ : a biomarker for progression of cutaneous squamous cell carcinoma. J Invest Dermatol (2014) 134:498-506. doi:10.1038/jid.2013.346

264. Santhekadur PK, Rajasekaran D, Siddiq A, Gredler R, Chen D, Schaus SE, et al. The transcription factor LSF: a novel oncogene for hepatocellular carcinoma Am J Cancer Res (2012) 2:269-85.

265. Amornsiripanitch N, Hong S, Campa MJ, Frank MM, Gottlin EB, Patz EF. Complement factor $\mathrm{H}$ autoantibodies are associated with early stage NSCLC. Clin Cancer Res (2010) 16:3226-31. doi:10.1158/1078-0432.CCR-10-0321

266. Bonavita E, Gentile S, Rubino M, Maina V, Papait R, Kunderfranco P, et al. PTX3 is an extrinsic oncosuppressor regulating complementdependent inflammation in cancer. Cell (2015) 160:700-14. doi:10.1016/j. cell.2015.01.004

267. Riihilä P, Nissinen L, Farshchian M, Kivisaari A, Ala-Aho R, Kallajoki M, et al. Complement factor I promotes progression of cutaneous squamous cell carcinoma. J Invest Dermatol (2015) 135:579-88. doi:10.1038/jid.2014.376

268. Arkwright PD, Riley P, Hughes SM, Alachkar H, Wynn RF. Successful cure of $\mathrm{Clq}$ deficiency in human subjects treated with hematopoietic stem cell transplantation. J Allergy Clin Immunol (2014) 133:265-7. doi:10.1016/j.jaci. 2013.07.035

269. Longhurst H, Cicardi M. Hereditary angio-oedema. Lancet (2012) 379:474-81. doi:10.1016/S0140-6736(11)60935-5

270. Mehta P, Norsworthy PJ, Hall AE, Kelly SJ, Walport MJ, Botto M, et al. SLE with $\mathrm{C} 1 \mathrm{q}$ deficiency treated with fresh frozen plasma: a 10-year experience. Rheumatology (Oxford) (2010) 49:823-4. doi:10.1093/rheumatology/kep387

271. Ariceta G, Besbas N, Johnson S, Karpman D, Landau D, Licht C, et al. Guideline for the investigation and initial therapy of diarrhea-negative hemolytic uremic syndrome. Pediatr Nephrol (2009) 24:687-96. doi:10.1007/ s00467-008-0964-1

272. Johnson S, Stojanovic J, Ariceta G, Bitzan M, Besbas N, Frieling M, et al. An audit analysis of a guideline for the investigation and initial therapy of diarrhea negative (atypical) hemolytic uremic syndrome. Pediatr Nephrol (2014) 29:1967-78. doi:10.1007/s00467-014-2817-4

273. Zuber J, Fakhouri F, Roumenina LT, Loirat C, Frémeaux-Bacchi V; French Study Group for aHUS/C3G. Use of eculizumab for atypical haemolytic uraemic syndrome and C3 glomerulopathies. Nat Rev Nephrol (2012) 8:643-57. doi:10.1038/nrneph.2012.214

274. Hillmen P, Young NS, Schubert J, Brodsky RA, Socié G, Muus P, et al. The complement inhibitor eculizumab in paroxysmal nocturnal hemoglobinuria. N Engl J Med (2006) 355:1233-43. doi:10.1056/NEJMoa061648

275. Legendre CM, Licht C, Loirat C. Eculizumab in atypical hemolytic-uremic syndrome. N Engl J Med (2013) 369:1379-80. doi:10.1056/NEJMc1308826

276. Nilsson B, Larsson R, Hong J, Elgue G, Ekdahl KN, Sahu A, et al. Compstatin inhibits complement and cellular activation in whole blood in two models of extracorporeal circulation. Blood (1998) 92:1661-7.

277. Risitano AM, Ricklin D, Huang Y, Reis ES, Chen H, Ricci P, et al. Peptide inhibitors of $\mathrm{C} 3$ activation as a novel strategy of complement inhibition for the treatment of paroxysmal nocturnal hemoglobinuria. Blood (2014) 123:2094-101. doi:10.1182/blood-2013-11-536573

278. Zhang Y, Nester CM, Holanda DG, Marsh HC, Hammond RA, Thomas LJ, et al. Soluble CR1 therapy improves complement regulation in C3 glomerulopathy. J Am Soc Nephrol (2013) 24:1820-9. doi:10.1681/ASN.2013010045 
279. Fridkis-Hareli M, Storek M, Mazsaroff I, Risitano AM, Lundberg AS, Horvath $\mathrm{CJ}$, et al. Design and development of TT30, a novel C3d-targeted C3/C5 convertase inhibitor for treatment of human complement alternative pathway-mediated diseases. Blood (2011) 118:4705-13. doi:10.1182/ blood-2011-06-359646

280. Hebecker M, Alba-Domínguez M, Roumenina LT, Reuter S, Hyvärinen S, Dragon-Durey M-A, et al. An engineered construct combining complement regulatory and surface-recognition domains represents a minimal-size functional factor H. J Immunol (2013) 1950(191):912-21. doi:10.4049/jimmunol. 1300269

281. Risitano AM, Notaro R, Pascariello C, Sica M, del Vecchio L, Horvath $\mathrm{CJ}$, et al. The complement receptor $2 /$ factor $\mathrm{H}$ fusion protein TT30 protects paroxysmal nocturnal hemoglobinuria erythrocytes from complementmediated hemolysis and C3 fragment. Blood (2012) 119:6307-16. doi:10.1182/ blood-2011-12-398792
282. Schmidt CQ, Bai H, Lin Z, Risitano AM, Barlow PN, Ricklin D, et al. Rational engineering of a minimized immune inhibitor with unique triple-targeting properties. J Immunol (2013) 1950(190):5712-21. doi:10.4049/jimmunol. 1203548

Conflict of Interest Statement: The authors declare that the research was conducted in the absence of any commercial or financial relationships that could be construed as a potential conflict of interest.

Copyright (c) 2015 Merle, Noe, Halbwachs-Mecarelli, Fremeaux-Bacchi and Roumenina. This is an open-access article distributed under the terms of the Creative Commons Attribution License (CC BY). The use, distribution or reproduction in other forums is permitted, provided the original author(s) or licensor are credited and that the original publication in this journal is cited, in accordance with accepted academic practice. No use, distribution or reproduction is permitted which does not comply with these terms. 